Est Ag 41 (2006) 475-516

\title{
Dios, el hombre y Jesucristo en Cervantes (I)
}

\section{DIOS}

Sería ilusorio pretender reunir en un apartado todos los usos que Cervantes hace de la palabra Dios en sus obras. Sólo en el Quijote aparece 510 veces 1 . Sería traer a este capítulo otros muchos temas. Aquí daré una serie de textos relacionados con Dios directamente. Excluyo los refranes, las exclamaciones y las frases hechas.

\subsection{Pruebas de la existencia de Dios}

Que la belleza es resplandor de la divinidad y por ella se puede subir hasta Dios era un lugar común en los neoplatónicos y en otros muchos autores paganos. También aparece en el Antiguo Testamento: "El cielo proclama la gloria de Dios, el firmamento pregona la obra de sus manos" (Sal 19 (18) 2). Dice Cicerón: "¿Quién es tan insensato que, después de dirigir su mirada al cielo, no crea en la existencia de los dioses? "2. Es un lugar común en los autores cristianos. Pregunté a todas las cosas que están fuera de mí y todas me dijeron: No somos el Dios que buscas. Él nos ha hecho. "Mi pregunta era mi mirada y su respuesta su hermosura"3. "La urdimbre de las criaturas, esta ordenadísima belleza, sin interrupción desde lo ínfimo a lo sumo y desde lo sumo a lo ínfimo, templada, sin embargo, con sus diferencias, alaba toda ella a Dios. ¿ ¿Por qué lo alaba? Porque al ver su hermosura, alabas tú a Dios en ella. La belleza de la tierra es, en cierto modo, la voz de la tierra [...].Tú la ves y con tu atenta mirada es como si le preguntaras [...]. ¿Es que, considerada en su conjunto la belleza de este mundo, no te responde a una sola voz: no me hice yo sino Dios?"4.

\footnotetext{
${ }^{1}$ Fernández Gómez, C., Vocabulario de Cervantes, Real Academia Española, Madríd 1962, apéndices.

2 CiCERÓN, Sobre la respuesta de los arúspices 19. Cicerón pertenecía al Colegio Sacerdotal de los Augures y defendió siempre la religión tradicional de los romanos, pero no está nada claro si él creía en algo.

${ }^{3}$ San Agustín, Confesiones 10, 6, 9 .

4 ÍD., Comentarios a los salmos 144, 13.
} 
De la belleza de un paisaje, orillas del Tajo, se dice: si las estrellas y el sol se mantienen de las aguas de acá abajo (afirmación sustentada por Plinio), "creo firmemente que las aguas de este río sean en gran parte ocasión de causar la belleza del cielo que le cubre, o creeré que Dios, por la mesma razón que dicen que mora en los cielos, en esta parte haga lo más de su habitación"5. "Tiene la belleza tanta fuerza para mover nuestros ánimos que ella sola fue parte para que los antiguos filósofos, ciegos y sin lumbre de fe que los encaminase, llevados de la razón natural y traídos de la belleza que en los estrellados cielos y en la máquina y redondez de la tierra contemplaban, admirados de tanto contento y hermosura, fueron con el entendimiento rastreando, haciendo escalas por estas causas segundas, hasta llegar a la primera causa de las causas, y conocieron que había un solo principio sin principio de todas las cosas"6. "Bartolomé (que así creo se llamaba el guiador del bagaje) viendo salir el sol tan alegre y regocijado, bordando las nubes de los cielos con diversos colores, de manera que no se podía ofrecer otra cosa más alegre y más hermosa a la vista, y con rústica discreción

${ }^{5} L G, \mathrm{VI}, 541$.

Abreviaturas de las obras de Miguel de Cervantes citadas en este artículo: $A L=" \mathrm{El}$ amante liberal", en Novelas ejemplares, edición de Jorge García López, estudio preliminar de Javier Blasco, presentación de Francisco Rico, Galaxia Gutenberg / Círculo de Lectores, Barcelona 2005. Cito la página; $B A=$ "Los baños de Argel", en Obras completas, edición de Ángel Valbuena Prat, Aguilar, Madrid 1960. Cito la jornada y la página; $C C=$ "La casa de los celos y selvas de Ardenia", en Obras completas, edic. cit. Cito la jornada y la página; $C E=$ "El celoso extremeño", en Novelas ejemplares, edic. cit.; $C N=$ "El cerco de Numancia", en Obras completas, edic. cit. Cito la jornada y la página; $C P=$ "El coloquio de los perros", en Novelas ejemplares, edic. cit.; $E I=$ "La española inglesa", en Novelas ejemplares, edic. cit.; $F S=$ "La fuerza de la sangre", en Novelas ejemplares, edic. cit.; $G E=$ "El gallardo español", en Obras completas, edic. cit. Cito la jornada y la página; $G I=$ " La gitanilla", en Novelas ejemplares, edic. cit.; $G S$ = "La Gran Sultana Doña Catalina de Oviedo", en Obras completas, edic. cit. Cito la jornada y la página; $I F=$ "La ilustre fregona", en Novelas ejemplares, edic. cit.; $J D=$ "El juez de los divorcios", en Entremeses, edición, introducción y notas de Eugenio Asensio, Castalia, Madrid 1993. Cito la página; $L G=$ "La Galatea", edición de Francisco López Estrada y María Teresa López García-Berdoy, Cátedra, Madrid 19992. Cito el libro y la página.; $L V=$ "El Licenciado Vidriera", en Novelas ejemplares, edic. cit.; $P$ = "Poesías", en Obras completas, edic. cit. Cito el número y la página.; $P S=$ "Los trabajos de Persiles y Sigismunda", edición de Carlos Romero Muñoz, Cátedra, Madrid 2003 . Cito el libro, el capítulo y la página; $P U=$ "Pedro de Urdemalas", en Obras completas, edic. cit. Cito la jornada y la página; $Q M$ = "Don Quijote de la Mancha", edición dirigida por Francisco Rico, Galaxia Gutenberg / Círculo de Lectores, Barcelona 2004. Cito la parte, el capítulo y la página; $R C=$ "Rinconete y Cortadillo", en Novelas ejemplares, edic. cit.; $R D=$ "El rufián dichoso", en Obras completas, edic. cit., Cito la jornada y la página; $R M=$ "El retablo de las maravillas", en Entremeses, edic. cit.; $R V=$ "El rufián viudo, llamado Trampagos", en Entremeses, edic. cit.; $T A=$ "El trato de Argel", en Obras completas, edic. cit. Cito la jornada y la página; $T F=$ "La tía fingida", en Novelas ejemplares, edic. cit.

6 LG, IV, 438-439. Léase la nota 168. 
dijo: Verdad debió de decir el predicador que predicaba los días pasados en nuestro pueblo, cuando dijo que los cielos y la tierra anunciaban y declaraban las grandezas del Señor. Pardiez, que, si yo no conociera a Dios por lo que me han enseñado mis padres y los sacerdotes y ancianos de mi lugar, le viniera a rastrear y conocer viendo la inmensa grandeza destos cielos (que me dicen que son muchos o, a lo menos, que llegan a once) y por la grandeza deste sol que nos alumbra"7.

Bartolomé en sus rústicas razones repite lo que ya hemos leído en $L a$ Galatea: sin la lumbre de la fe, por la sola razón natural, viendo la belleza de los cielos y siguiendo las huellas de Dios en las criaturas se puede llegar hasta la primera causa de las causas. Las palabras del predicador repiten las del Salmo 19 (18), 2). Escribió san Pablo: "Porque lo que puede conocerse de Dios lo tienen a la vista, Dios mismo se lo ha puesto delante; desde que el mundo es mundo, lo invisible de Dios, es decir, su eterno poder y su divinidad, resulta visible para el que reflexiona sobre sus obras, de modo que no tienen disculpa" (Rom 1, 19-20). Dios se revela en la creación. Es indiscutible que se puede llegar a Él por la razón, pero los hombres se dejaron llevar de sus pasiones y su razón se obnubiló (Cf. Rom 1, 21-32). "Desde las cosas corporales [...] llegar a las incorporales"8.

Mención especial merece la belleza de la mujer. "El deseo que en todos había de ver el sol de la hermosura de Isabela, que tantos meses se les había eclipsado [...]. Con su gallardía, dando ocasión para que todos alabasen a Dios en ella, salió Isabela de su casa a pie [...]. Unos bendecían a sus padres, otros al cielo, que de tanta hermosura la había dotado"9. "De esa beldad peregrina / la perfección soberana / que al Cielo nos encamina / [...]. Que al alma que en sí contiene / ser tan alto y milagroso / se le diese el velo hermoso / más que el mundo tuvo o tiene" 10 . Como al alma inmortal no le satisfacen las bellezas efímeras, desde ellas penetra en el centro del alma y sube hasta la belleza perfecta. "Mi alma tu belleza, al mundo rara, / vio tan curiosamente que no quiso / en el rostro parar la vista clara. / Allá en el alma tuya

${ }^{6} L G, \mathrm{IV}, 438-439$. Léase la nota 168.

7 PS, III, 11, 540-541. De acuerdo con la concepción tolemaica del universo, los cielos eran: la Luna, Mercurio, Venus, el Sol, Marte, Júpiter, Saturno, las estrellas fijas, el llamado "cristalino" (el cielo de las aguas cristalinas), el Primer móvil y el Empíreo. Los rústicos no tenían más fuente de "cultura literaria" que el sacerdote del lugar y los predicadores (Sancho lo admite en varios lugares), y como fuente de "cultura oral" los padres y los ancianos del lugar.

${ }^{8}$ San Agustín, Retractaciones 1, 6 .

${ }^{9} E I, 256$.

${ }^{10} L G$, II, 288 
un paraíso / fue descubriendo de bellezas tantas / que dan de nueva gloria cierto aviso. / Con estas ricas alas te levantas / hasta llegar al Cielo, y en la tierra / al sabio admiras, y al que es simple espantas [admiras]/. [Trasciende la belleza corporal y] del alma el escondido centro / mira y contempla mil bellezas puras / que le acuden y salen al encuentro. / Mortales y caducas hermosuras / no satisfacen a la inmortal alma / si de la luz perfecta no anda a escuras"11. Un bello rostro de mujer se consideraba como un trasunto de la belleza divina. Hay textos abundantes en Cervantes y en toda la lírica del Siglo de Oro. "Un bello rostro y figura, / aunque caduca y mortal, / es un traslado y señal / de la divina hermosura"12.

Nos parece estar leyendo el último capítulo de $\mathrm{El}$ cortesano, de Castiglione, libro que Cervantes conocía muy bien. En él, el Bembo, tocado del aliento divino, habla del amor y la belleza, "rayo divino"13, con acentos neoplatónicos; de la belleza corporal; de la belleza en sí misma, separada de toda materia; de la idea de belleza que se derrama por las criaturas; de la belleza que descubre el alma al entrar dentro de sí y contemplar su propia sustancia, "casi como recordada [despertada] de un pasado sueño, abre aquellos ojos que todos tenemos y pocos los usamos y ve en sí misma un rayo de aquella luz que es la verdadera imagen de la hermosura angélica comunicada a ella, de la cual también ella después comunica al cuerpo una delgada y flaca sombra"14. Contemplando esta belleza, "ciega para las cosas terrenas", "siente un cierto escondido olor de la verdadera hermosura angélica; y así arrebatada con el resplandor de aquella luz, comienza a encenderse y a seguir tras ella con tanto deseo, que casi llega a estar borracha y fuera de sí misma por sobrada codicia de juntarse con ella, pareciéndole que allí ha hallado el rastro y las verdaderas pisadas de Dios, en la contemplación del cual, como en su final bienaventuranza, anda por reposarse; y así ardiendo en esta más que bienaventurada llama, se levanta a la su más noble parte que es el entendimiento, y allí, ya no más ciega con la oscura noche de las cosas terrenales, ve la hermosura divina, mas no la goza aún del todo perfectamente porque la contempla solamente en su entendimiento particular, el cual no puede ser capaz de la infinita hermosura universal [...]. En el postrer grado de perfección la lleva del entendimiento particular

\footnotetext{
11 LG, III, 310-312.

${ }^{12}$ LG, I, 232. Cf. Rıco, F., El pequeño mundo del hombre, Castalia, Madrid 1970, pp. $142-$ 143.

13 Castiglione, B. de, El cortesano, traducción de Boscán, introducción y notas de Rogelio Reyes Cano, Espasa-Calpe, Madrid 19845, 1. IV, c. 7, p. 347.

14 ÍD., ib., p. 352. Cf. San Agustín, Confesiones 7, 10, 16.
} 
al entendimiento universal; adonde el alma, encendida en el santísimo fuego por el verdadero amor divino, vuela para unirse con la natura angélica, y no solamente en todo desampara a los sentidos y a la sensualidad con ellos, pero no tiene más necesidad del discurso de la razón, porque, transformada en ángel, entiende todas las cosas inteligibles, y sin velo o nube alguna ve el ancho piélago de la pura hermosura divina, y en sí le recibe, y recibiéndole goza aquella suprema bienaventuranza que a nuestros sentidos es incomprensible"15. Bembo, henchido de exaltación religiosa, vueltos los ojos al cielo, invoca y exalta el amor divino, de modo que "cada uno ya parecía sentir en su alma una cierta centella del amor divino que le movía y le levantaba el espíritu, y así todos deseaban oír más"16.

$\mathrm{El}$ amor y la belleza son de origen divino, resplandores de la divinidad. El amor es una fuerza que viene de Dios e impulsa a todos los seres hacia el Uno, que es "el pío [deseo vivo y ansioso de algo] general de todas las cosas, y el fin y como el blanco adonde envían sus deseos todas las criaturas"17. Las cosas bellas impresionan los sentidos y en ellas se vislumbra la belleza divina ( $₫$ Y las feas? Son consecuencia del pecado original). Alguien queda deslumbrado por la hermosura de una mujer, cegado por su visión, y en ella percibe a la vez un destello de la belleza absoluta. Es el primer peldaño. La imaginación y la fantasía conservan esas imágenes y crean otras más puras, y las envían todas a la memoria. Queda ya enamorado de la belleza divina: segundo grado. La razón discursiva extrae de la belleza corpórea la incorpórea, lo incorruptible de lo corruptible. Contempla la belleza de su propia alma y la idea ejemplar de la belleza. Retirado el amante en su interior, su alma se va desprendiendo de la materia, se purifica, se espiritualiza, se endiosa. Es el tercer grado. A continuación, viene el conocimiento abstracto, unitivo y de orden superior. Contempla el universo angélico y el alma del mundo. Puede incluso intuir, fugaz y oscuramente, la belleza absoluta, la luz sobre toda luz como un raudo lampo. Pero sólo tras la muerte alcanzará la fruición definitiva de la Belleza y la unión con la divinidad. Se trata de un proceso gradual y ascendente, las famosas ascensiones "platónicas" del alma a Dios, lleno de sufrimientos y penalidades contra las atracciones mundanas que hay que vencer. Pero los grados no están separados unos de otros, de suerte que haya que terminar uno para empezar otro. Como en las vías místicas (purgativa, iluminativa, unitiva), se cruzan y

\footnotetext{
15 Íd., ib., pp. 352-353.

16 ÍD., $i b .$, p. 355.

17 LEÓn, fray Luis de, De los nombres de Cristo, edición de Cristóbal Cuevas, Cátedra, Madrid 1977, De los nombres en general, p. 155.
} 
entretejen. Es una vía de perfección, de vuelta al paraíso perdido, de endiosamiento, de salvación, de realización diríamos hoy. Pero no todos llegan hasta el final. Muchos van quedando en los distintos tramos del camino. Algunos no pasan del "ardor de amores", del frenesí sexual.

El sentimiento más común de esta poesía neoplatónica es el de ausencia $^{18}$, que produce sufrimiento, tristeza, depresión, el "muero porque no muero". Centro del alma, rayo divino, grados de hermosura, beso en la boca, ausencia y presencia del amado, noche oscura, el no ser de las cosas, centella de amor, llama, suave abrasamiento o ardimiento tórrido, fuego que destruye, transformación en el amado, muerte que da vida, entrar dentro de sí y salir fuera, embriaguez, enfermedad de amor, chispa del alma, ápice del alma... El caudaloso léxico del amor humano desembocará en los espirituales del siglo XVI y lo utilizarán para hablar del amor entre Dios y el alma. Sobre este trasfondo neoplatónico hay que leer a los espirituales del siglo XVI, e incluso de aquí hay que partir para entender la unión con Dios, de que hablan los místicos (hay que contar también con el Cantar de los cantares, que ellos interpretaban anagógicamente), que la comparan con la unión sexual, una especie de orgasmo a lo divino; lo que no deja de ser extraño en ellos, que tan enemigos eran del cuerpo. Jerónimo Gracián dice del éxtasis que "es como la cópula del matrimonio divino". Se ha dicho que en esas alturas el amor no puede ser tibio, sino el de mayor exaltación. Se trata de una aventura estrictamente espiritual, que no es contradictoria "con la presencia en ella de imágenes eróticas: el amor sólo tiene un lenguaje, y para expresar la unión es forzoso acudir a sus zonas más cálidas"19. Pero de la unión con Dios se había hablado durante siglos, y se sigue hablando, y no siempre se ha recurrido a las zonas más tórridas del sexo. Sus códigos culturales no tienen nada que ver con los nuestros.

"Amor, que es virtud entera, / con otras muchas que alcanza, / de una en otra semejanza / sube a la causa primera" 20 . Se llama causa primera porque no es efecto de ninguna otra y ella es causa de todas las causas segundas y concurre con cada una de ellas prara producir el correspondiente efecto. Amor, "raíz de adonde nace / la venturosa planta / que al cielo nos levan-

18 Cf. Garrote PÉrez, F., "La "ausencia" en la poesía neoplatónica, modelo humanista de escisión personal y de imposibilidad de realización", en Silva, 3 (2004), pp. 169-202; LÁZAro CARreter, F., "Para una lectura espiritual del Cántico espiritual de san Juan de la Cruz", en Clásicos españoles. De Garcilaso a los niños pícaros, Alianza, Madrid 2003, pp. 220-226.

19 LÁzAro Carreter, F., ib., ib., p. 239. Cf. Rodríguez DE LA Flor, F., La península metafisica. Arte, literatura y pensamiento en la España de la Contrarreforma, Biblioteca Nueva, Madrid 1999, c. 7, pp. 233-266.

${ }^{20} L G, \mathrm{I}, 232$. 
ta. / [...]. Instinto natural que nos conmueve / a levantar los pensamientos, tanto / que apenas llega allí la vista humana; / escala por do sube, el que se atreve, / a la dulce región del cielo santo"21. Cervantes sigue a los tratadistas neoplatónicos, en especial a Bembo y a León Hebreo: "En las criaturas existe la imagen y semejanza de Dios gracias a esa belleza finita participada [...]. La belleza infinita del Creador se dibuja y refleja en la belleza finita [...]. No obstante, no mide la imagen de lo divino imaginado, sino que más bien será simulacro, semejanza e imagen" 22 .

Belleza, orden del mundo, resplandor de la divinidad en las criaturas, huellas de Dios, grados del ser, causa primera o causa de las causas, principio sin principio... Son categorías mentales que en Occidente arrancan de Platón y llegaron hasta el siglo XVIII. Aún persisten en algunos cerebros. La mirada se tiende, gozosa, por el enrejado de las criaturas, contempla a Dios en las cosas mínimas y en su trabazón maravillosa -maximus in minimis cernitur esse Deus-, sigue por las criaturas superiores, encontrando siempre nuevos motivos de admiración, hasta abarcar la máquina entera del universo. Contemplar a Dios en las criaturas, en el clarear de una mañana virgen, en el incendio de una puesta de sol, perdido en un bosque rumoroso o absorto en el silencio y sosiego de una noche que nos mira con infinitos ojos parpadeantes era un ejercicio muy recomendado por los espirituales de antaño. La presencia de Dios era para ellos tan evidente como las realidades terrestres que contemplaban. Aun más evidente, porque era Dios, el Ser de veras, el que las sutentaba y les daba el ser, un ser poco más que aparente, reverberación, en esta ladera, del Sol, que alumbra en la otra. Es esta contemplación la que se celebra en el Cántico de las criaturas, que la tradición atribuye a san Francisco de Asís, y, cuando ya se creía olvidada, reapareció jubilosa, incontenible, en el verso libre de las Cinq odes, de Claudel.

Grados del ser, escala de las criaturas o cadena del ser. Decir grados del ser es decir orden y jerarquía. En esa cadena cada uno tiene su puesto. Se partía de lo más ínfimo, de lo inanimado, se pasaba por lo vegetal, se continuaba por los animales, desde la especies inferiores a las superiores, se llegaba al hombre, se penetraba en los cielos, en las jerarquías angélicas, y se subía hasta el trono de la Majestad divina. Era una escala de perfección en el universo, pero también una escala de perfeccionamiento espiritual, por la que se podía ascender desprendiéndose de lo terreno, de los afectos huma-

$21 L G, I V, 449-450$. Subir de peldaño en peldaño por "la escala de la belleza" está ya en Platón, El banquete 209-212.

22 Hebreo, León, Diálogos de amor, introducción, edición y notas de J. M. Reyes Cano, PPU, Barcelona 1986, p. 466. 
nos, para ir adquiriendo cualidades divinas, deificándose. Tal es el supuesto que estaba en las mentes de aquellos hombres. Tal es el supuesto que preside y estructura el Persiles ${ }^{23}$.

¿Grados del ser? El orden social con sus grados y jerarquías es una invención de los hombres, y en los otros seres tampoco hay una escala de perfección. La evolución dio al traste con esta mentalidad. ¿Huellas de Dios en las criaturas? Las de su ausencia. "No he visto nunca parecerse nada la raíz de la planta a su flor ni a su fruto. Probablemente, pues, es condición de toda causa no parecerse nada a su efecto. Creer lo contrario fue el error cometido por la interpretación mágica del mundo"24. Buscar las huellas de lo divino en las criaturas es absurdo. No hay datos empíricos que puedan fundamentar esa experiencia. Es lo postulado, no lo dado ${ }^{25}$. La creación no crea dependencia. Deja que el mundo sea lo que es, autónomo, y que el hombre sea libre, creador. Dios no interviene en las causas segundas. El hijo, como ha visto muy bien Julián Marías, biológica y psicológicamente viene de sus padres; pero como persona, no; es una innovación de realidad, creación de una realidad nueva e irreductible. Como persona, no hay en él huellas de sus padres. Desde esta creación personal quizá podría comprenderse la creación y un posible Creador 26 .

Sabido es que las cinco vías para demostrar la existencia de Dios -el movimiento, las causas, la contingencia, los grados del ser y el orden o belleza del mundo- no prueban nada ${ }^{27}$. Vivimos en un mundo muy distinto del de los griegos, del que hemos heredado esas categorías mentales, que hoy son cadenas que nos aherrojan. Hay que librarse de ellas, y desde la altura de nuestro tiempo -desde nuestra mentalidad científica y filosófica y desde la nueva hermenéutica aplicada a los textos del Nuevo Testamento- hablar del Dios que se ha manisfestado en Jesucristo, del Dios, que "es amor" (1Jn $4,8)$, y nos llama a amar.

23 Cf. Avalle-Arce, J. B., en Cervantes, Miguel de, Los trabajos de Persiles y Sigismunda, edición, introducción y notas de, Castalia, Madrid 1969, introducción, pp. 20-21. Cf. nota 13 de la p. 20; GREEN, Otis H., España y la tradición occidental, Gredos, Madrid 1969, t. II, c. 1, pp. 23-41; YndurÁIn, D., Aproximación a san Juan de la Cruz, Cátedra, Madrid 1990, pp. 51-60.

24 ORTEGA y GASSET, J., Ideas y creencias, Espasa-Calpe, Madrid $1968^{7}$, p. 38.

25 Cf. ÍD, ¿Qué es filosofía?, Espasa-Calpe, Madrid 1973, lección V, pp. 86-88.

26 Cf. Marías, J., Antroplogía metafísica, Revista de Occidente, Madrid 1973, c. 4, pp. 35 37; ÍD., Persona, Alianza, Madrid 1996, c. 15, pp. 121-126.

27 Cf. CASADO, F., “¿Es válida la demostración racional de la existencia de Dios a través de las vías?", en Estudio Agustiniano, 5 (1970), pp. 627-639; VEGA, J., "Sobre el "amor mutuo" de los cristianos", en Estudio Agustiniano, 31 /1996), pp. 99-103. 


\subsection{El Dios verdadero}

"Una de las cosas en que ponían el sumo bien los antiguos filósofos, que carecieron del verdadero conocimiento de Dios, fue en los bienes de la naturaleza, en los de la fortuna, en tener muchos amigos y en tener muchos y buenos hijos"28. Julio César dijo que la mejor muerte era "la impensada, la de repente y no prevista; y aunque respondió como gentil y ajeno del conocimiento del verdadero Dios, con todo eso dijo bien, para ahorrarse del sentimiento humano"29. Los gentiles descubrieron algunas verdades, aunque carecían de la lumbre de la fe. Llegaron a conocer la existencia de "un solo principio sin principio de las cosas" y por la belleza del mundo llegaron hasta Dios, pero no llegaron al conocimiento del "verdadero Dios", que es el Dios cristiano, ni al "verdadero conocimiento de Dios", que sólo está al alcance de los cristianos. Descubrieron algunas otras verdades como la inmortalidad del alma y la eternidad de la vida futura como he escrito en $L a$ fe en Cervantes. Estamos ya muy lejos de los fervores de los humanistas por los filósofos gentiles.

Fuera de la Iglesia no se conoce a Dios, al verdadero Dios, que es el Dios cristiano, y como no conocen a Dios, todos al infierno, como lo había dicho el Concilio de Florencia: "Fuera de la Iglesia católica no hay salvación"30. "Dígame, señor -prosiguió Sancho-: esos Julios o Agostos [Julio César y Augusto], y todos esos caballeros hazañosos que ha dicho, que ya son muertos, ¿dónde están agora? -Los gentiles -respondió don Quijotesin duda están en el infierno; los cristianos, si fueron buenos cristianos, o están en el purgatorio o en el cielo" 31 . Cuando se leen las cartas de los misioneros, extraña la prisa que se daban por llevar el evangelio a todos los hombres y por bautizarlos cuanto antes. Las de san Francisco Javier son muy elocuentes. Es éste un aspecto muy difícil de comprender desde nuestra mentalidad. ¡Tan distintos somos de ellos!

En el Persiles, Ricla, convertida al catolicismo, habla de sus "dos hijos, como los que aquí veis, que acrecientan el número de los que alaban al Dios verdadero"32. Al llegar a Lisboa, en el monasterio de Belén, los peregrinos

\footnotetext{
${ }^{28} Q M, \mathrm{II}, 16,824$.

${ }^{29} Q M$, II, 24, 911. Lo cuenta Suetonio en Los doce Césares. Lo repiten, entre otros, Petrarca y Erasmo. Cf. la nota a este pasaje. 1351.

30 DenzINGER-SCHÖNMETZER, Enchiridion Symbolorum, Herder, Barcinone1973 ${ }^{35}, \mathrm{n}^{\circ}$.

31 QM, II, 8, 755. Cf. VeGA, J., "La fe en Cervantes", en Religión y Cultura, 52 (2006), pp. 44-50.

32 PS, I, 6, 177.
} 
adoraron "al verdadero Dios"33. De la naturaleza se dice que es "mayordoma del verdadero Dios" 34 , expresión que está también en La Galatea y muy frecuente en la literatura de la época ${ }^{35}$. "Por la estrecha cuenta que pensaba dar en breves horas al verdadero Dios"36. "Tenía esperanza en el verdadero Dios, en quien él creía, aunque mal cristiano, que lo había de disponer de otra manera" 37 .

\subsection{Los atributos de Dios}

A partir de las criaturas -via causalitatis-, el hombre intenta hacerse una idea de Dios. Se eliminan las cualidades que se juzgan negativas - via negationis-, se afirman las positivas y se elevan a su máxima perfección -via eminentiae-. Dios poseerá todos esos atributos en grado sumo. Cada época y cada hombre se formará su idea de Dios según la estimativa de valores y contravalores. Pero esa idea el tiempo la deshará y habrá que volver a empezar. "Mi idea de Dios es distinta cada vez que la concibo"38. "Para inventar a Dios, nuestra palabra / busca, dentro del pecho, / su propia semejanza y no la encuentra. / [...]. Y Su nombre sin letras, / escrito a cada instante por la espuma, / se borra a cada instante / mecido por la música del agua; / y un eco queda sólo en las orillas. / [...]. Otra vez ciegamente desde dentro / va a pronunciar Su nombre. / Y otra vez se ensombrece el pensamiento, / y la voz no le encuentra. / Dentro del pecho está. / Tus hijos somos, / aunque jamás sepamos / decirte la palabra exacta y Tuya, / que repite en el alma el dulce y fijo / girar de las estrellas"39. "Dios es inefable. Es más

33 PS, III, 1, 434.

34 PS, III, 11, 543.

35 LG, IV, 439. Cf. Green, Otis H., ib., t. II, c. 3, pp. 89-108; GARrote PÉrez, F., La naturaleza en el pensamiento de Cervantes, Universidad, Salamanca 1979, c. 1, pp. 13-16; CASTRO, A., El pensamiento de Cervantes, Noguer, Barcelona, c. 4, pp. 159-173. Castro interpretó a Cervantes dentro de la corriente naturalista, no-cristiana, del Renacimiento italiano; pero la expresión "mayordoma de Dios" es la natura naturans medieval. Se incorpora lo nuevo sin desgajarse del pasado. La naturaleza y Dios son completamente distintos y el poder que aquella tiene se lo ha dado Dios. Lo veremos en los atributos de Dios.

36 LG, II, 277.

$37 A L, 135$.

38 Unamuno, M. de, Del sentimiento trágico de la vida, introducción de Pedro CerezoGalán, Espasa-Calpe, Madrid $1993^{5}$, c. 5, p. 124. De aquí las contradicciones sobre Dios que hay en Unamuno. Hay que aceptar sus textos como son, sin tratar de aliñarlos. Es en las contradicciones donde se encuentra el auténtico Unamuno, que nos incita a pensar.

39 Panero, L., Escrito a cada instante, en Poesía, Culltura Hispánica, Madrid 1963, nº 25 , p. 133. Cf. ConNolly, E., Leopoldo Panero: la poesía de la esperanza, Gredos, Madrid 1969, c. 5 , pp. $137-172$. 
fácil decir lo que no es que lo que es [...]. Preguntas qué es. Lo que el ojo no vio, ni el oído oyó, ni hombre alguno imaginó $(1$ Cor 2,9$)$. ¿Por qué exiges que diga la lengua lo que no ha comprendido el corazón?"40.

Dios es Creador, atributo que sólo a Él le pertenece. "El sumo Hacedor"41, "el Hacedor de todas las cosas"42, "¡oh soberano Hacedor del cielo!"43, "el Hacedor de tierra y cielo"44. Un turco se queja de que se han quedado cortos en las alabanzas de la Sultana, y en estilo de hipérbole sacra continúa: "Cielo te la hice yo, / con pies humanos, señor. / -A hacerla su Hacedor / acertaras. -Eso no: / que esos grandes atributos / cuadran solamente a Dios" 45 . El cielo cubre la tierra en todas partes, también a los antípodas, "como lo ordenó la naturaleza, mayordoma del verdadero Dios, Criador del cielo y de la tierra"46, texto en el que está claro que la naturaleza, por mucho poder que tenga, no anula a Dios, pues es Él el que le ha dado el poder y es Él el Creador. Recordando un pasaje de los Proverbios bíbli$\cos (8,22-36)$, que la tradición ha aplicado alguna vez a la Virgen, Cervantes nos dice que "fabricó para sí Dios una casa / de santísima y limpia y pura masa", "antes que de la mente eterna fuera / saliesen [los] espíritus alados, / y antes que la veloz o tarda esfera / tuviese movimientos señalados, / y antes que aquella oscuridad primera / los cabellos del Sol viese dorados" 47 . El "plasmador del mundo" se llama a Dios en el Quijote 48 . "Y cuando fuera ya más conocido / el propio Hacedor de tierra y cielo" 49 . "Esa rara beldad, que nos adiestra / a conocer al Hacedor del cielo" 50 .

\footnotetext{
40 San Agustín, Comentarios a los salmos 85, 12. Es este un leitmotiv en sus escritos: todo lo que pienses sobre Dios no es Dios.

$41 P, 4,43$.

$42 L G$, III, 341.

${ }^{43} L G, \mathrm{I}, 201$.

$44 T A$, III, 132.

$45 \mathrm{GS}, \mathrm{I}, 375$.

46 PS, III, 11, 543. En este punto, no tiene razón Américo Castro, al hablar de la naturaleza divina e inmanente, que se basta a sí misma, en Cervantes,. Cf. El pensamiento de Cervantes, edic. cit., c. 4, pp. 159-173. Cf. GREEN, Otis H., España y la tradición occidental, Gredos, Madrid 1969, t. II, c. 3, pp. 89- 108. Un solo texto de Fray Luis de LEÓN: el alma está adaptada "al cuerpo que la naturaleza le da [...]. Ni sería su casa de la alma la carne fabricada por Dios para su perfeción y descanso" (De los nombres de Cristo, edic. cit., 1. 3, Cordero, p. 578). ¿Se puede hablar de naturaleza divina e inmanente en fray Luis?. En un mismo texto aparecen la naturaleza y Dios, que no se oponen, porque es Dios el que le ha dado el poder. Está claro que habla de la natura naturans,

47 PS, III, 5, 77.

${ }^{48} Q M$, I, 46, 588. Cf. MuÑoz IGLESIAS, S., Lo religioso en el Quijote, Estudio Teológico de San Ildefonso, Toledo 1989, c. 6, pp. 131-144.

${ }^{49} \mathrm{CN}, \mathrm{I}, 153$.

50 CC, II, 244.
} 
Expresamente se dice que Dios creó al hombre. Ninguna obra tan perfecta como el hombre, "que, en todas las obras hechas por el mayordomo de Dios, Naturaleza, ninguna es de tanto primor ni que más descubra la grandeza y sabiduría de su Hacedor"51. "El Hacedor y Criador nuestro" 52. "A cada uno mate su ventura, o Dios, que le hizo"53. "De menos me hizo Dios"54 (el refrán continúa "... que nos hizo de la nada). "Dios nos echó en el mundo, Él sabe para qué" 55. "Cuando Dios crió a nuestro primero padre en el Paraíso terrenal, dice la divina Escritura que infundió Dios sueño en Adán y que, estando durmiendo, le sacó una costilla del lado siniestro, de la cual formó a nuestra madre Eva"56. Los penitenciarios "discurrieron por la verdad de la creación del hombre y del mundo" 57 . Las almas "de una misma masa en sus principios creadas y formadas por su Hacedor" 58 .

Dios es el Bien sobre todos los bienes, el "Bien que deseamos"59. El pastor Lauso canta el desdén que le ha librado del amor y le ha devuelto la razón, que, "siendo agora señora, me conduce / do el Bien eterno más se muestra y luce" 60 .

Dios es impecable, infinito, omnipotente, eterno. "Dios es impecable, de do se infiere que nosotros somos autores del pecado"61. "Mente eterna [...] y duración infinita"62. "Eterno tribunal del Dios eterno"63. En Él "no hay minoridad de poder [...], bien infinito. No hace cosa mal hecha. [...Siendo todo por referencia a Él] punto finito. / Los atributos de Dios / son iguales [...]. / La mayor ofensa haces / a Dios que puedes hacer; / que en no esperar y temer / parece que le deshaces, / pues vas contra el atributo / que Él tiene de omnipotente, / pecado el más insolente, / más sin razón y más bruto" 64 . "¡Bendito sea el poderoso Dios, que tanto bien me ha hecho!", dijo don

51 PS, IV, 439-440.

$52 L G, \mathrm{IV}, 440$

$53 Q M, \mathrm{I}, 26,322$.

$54 Q M$, II, 33, 989.

55 QM, II, 40, 1042 .

$56 \mathrm{QM}, \mathrm{I}, 33,424$. Repité lo que se dice en el Génesis 2, 21-24. Que la costilla fue sacada del lado izquierdo, del lado del corazón, es creencia antigua y popular, que se afianzó con otra creencia en la que se afirmaba que Cristo quiso que la lanza de Longinos penetrase en ese hueco por amor a la humanidad. Léase la nota a este pasaje.

57 PS, IV, 5, 657.

58 PS, I, 18, 243.

$59 P, 4,43$.

${ }^{60} L G, \mathrm{~V}, 525$.

${ }^{61} \mathrm{CP}, 598$.

${ }^{62} P S$, III, 5, 477-478.

${ }^{63} R D, \Pi$ II, 354.

$64 R D$, II, 351-352. 
Quijote, "dando una gran voz"65, al despertar de un profundo sueño, próximo ya a la muerte .

Dios es la Verdad y la Sabiduría. "La historia es como cosa sagrada, porque ha de ser verdadera, y donde está la verdad, está Dios, en cuanto a verdad"66. "Si va a decir verdad, que en fin es hija de Dios"67. Dios lo sabe todo. "Basta que me entienda Dios, mujer -respondió Sancho-, que Él es el entendedor de todas las cosas"68. "Encomendémoslo todo a Dios, que Él es el sabidor de las cosas que han de suceder en este valle de lágrimas, en este mal mundo que tenemos"69. "A solo Dios está reservado conocer los tiempos y los momentos, y para Él no hay pasado ni porvenir, porque todo es presente"70. "Dios sabe la verdad de todo"71. "Él sabe que ha de ser de mí, y basta"72. Habla un enamorado: "Pero si Amor es dios, es argumento / que nada ignora, y es razón muy buena / que un dios no sea cruel"73.

Dios mora en las alturas. Es el Altísimo, el Señor, el Soberano. "Todos lo males que llaman de daño vienen de la mano del Altísimo y de su voluntad permitente"74. Dios es el Altísimo, más alto que los señores de la tierra, a los que el vasallo ve en las alturas. Es la autoridad señorial suprema, pero muy distinto de los señores de este mundo. "Muy diferentes son los señores de la tierra del Señor del cielo"75. "Haréis un gran servicio a Nuestro Señor"76. Es el "soberano Dios"77. "¡Oh soberano Hacedor del cielo!"78. Todo le está presente y Él está presente en todo con su ser y su poder.

${ }^{65} Q M, I I, 74,1329$. "Dando una gran voz". La expresión coincide con el grito de Jesús al morir según los sinópticos: Mt 27, 50; Mc 15, 37; Lc 23, 46. Cf. MonROY, J. A., La Biblia en el Quijote, Clie, Terrassa (Barcelona) 2005, c. 6, pp. 204-220. Cervantes conocía muy bien la Biblia.

${ }^{66} Q M$, II, 3, 712. Léase la nota 59 a este pasaje: "La idea es profundamente agustiniana, y aun la frase misma parece traducción de san Agustín". En el tomo II, notas complementarias, p. 444, se dan algunos textos de san Agustín y de Petrarca, buen conocedor de san Agustín. Se pueden citar también algunos textos bíblicos. Se puede añadir este otro texto de san Agustín: "Dios es la verdad" (De la utilidad de creer 15, 33).

67 PS, III, 10, 534.

${ }^{68} Q M$, II, 5, 724. Léase la nota 10 a este pasaje.

${ }^{69} Q M$, II, $11,776$.

$70 \mathrm{QM}, \mathrm{II}, 25,921$. "No es cosa vuestra conocer los tiempos o los momentos que el Padre ha reservado a su poder" (Hch 1,7$)$.

71 QM, II, 40, 1042 .

$72 C P, 600$.

73 CC, III, 258.

74 CP, 598.

$75 \mathrm{CP}, 557$.

$76 \mathrm{QM}, \mathrm{I}, 27,338$.

$77 L G, \mathrm{I}, 189$.

${ }^{78} L G, \mathrm{I}, 201$. 
"Porque uno de los mayores atributos de Dios (que todos son iguales) es el estar en todo lugar, por potencia, por esencia y por presencia"79. "Para Él no hay pasado ni porvenir, porque todo es presente" 80 .

Dios es la Justicia y será Juez. Doña Ana, a punto de morir, dice desesperada: en Dios está ausente la "misericordia", "no la justicia: "La justicia de Dios me tiene a raya; / no me ha de perdonar, por ser tan justo; / al malo la justicia le desmaya"81. "Lucifer se queja: "En mí se extiende y en Adán se encoge, / la justicia de Dios, manso y severo"82. "Pero el justo cielo, que pocas o ningunas veces deja de mirar o favorecer a las justas intenciones, favoreció las mías"83. Camila finge una escena: "Viendo allá, donde quiera que fuere, la pena que da la justicia desinteresada y que no se dobla al que en términos tan desesperados [decisión de suicidarse] me ha puesto" 84. "Dios está en el cielo, que juzga los corazones"85. "Dios sufre a los malos, pero no para siempre"86. "Dios está en el cielo, que ve las trampas, y será Juez de quién hace más mal"87.

Dios es Médico. "Los otros dicen que me encomiende a Dios, que todo lo cura"88. "Señor Roque, vuestra merced está enfermo, conoce su dolencia, y el cielo, o Dios, por mejor decir, que es nuestro médico, le aplicará medicinas que le sanen, las cuales suelen sanar poco a poco, y no de repente y por milagro; y más, que los pecadores discretos están más cerca de enmendarse que los simples; y pues vuestra merced ha mostrado en sus razones su prudencia, no hay sino tener buen ánimo y esperar mejoría de la enfermedad de su conciencia"89. El título de Médico dado a Cristo es frecuente en los Padres de la Iglesia, muy especialmente en san Agustín.

Dios es misericordioso. Leonida, moribunda, pide a Dios clemencia: "¡Oh soberano Hacedor del cielo, encoge la mano de tu justicia y abre la de tu misericordia para tenerla de esta alma, que presto te dará cuenta de las ofensas que te ha hecho"90. A doña Ana, que teme entrar en el combate

${ }^{79} \mathrm{PS}, \mathrm{IV}, 5,658$. Que todos son iguales. El editor cree "que no es improbable que se trate de una errata, por aunque todos son iguales". Esta última frase aparece otras dos veces en Cervantes.

$80 Q M$, II, 25, 921 .

$81 \mathrm{RD}, \mathrm{II}, 352$.

$82 R D$, III, 361 .

${ }^{83} Q M$, I, 28, 363 .

$84 Q M, \mathrm{I}, 34,450$.

$85 Q M$, II, 33, 993. Cf. Lc 16, 15.

$86 Q M$, II, 40, 1043.

$87 Q M$, I, 30, 387.

$88 L G, \mathrm{I}, 174$.

${ }^{89} Q M$, II, 60, 1229-1230.

$90 L G, \mathrm{I}, 201$. 
final, el P. Cruz le recuerda quién es el Padrino y quién es el Juez: "Confiad en el Padrino / y en el Juez, que es mi Dios" 91: "Nacidas somos; no hizo Dios a nadie / a quien desamparase" 92. "Soy devoto de Nuestra Señora, y confío siempre en la misericordia infinita de Dios Nuestro Señor" 93 , dice el Caballero del Verde Gabán. "A su misericordia me atengo"94. Muéstrate "piadoso y clemente", aconseja don Quijote a Sancho, "porque aunque los atributos de Dios todos son iguales, más resplandece y campea a nuestro ver el de la misericordia que el de la justicia"95. También Erasmo aconseja al príncipe, a semejanza de Dios, guiarse más por la misericordia que por el castigo 96 . "Y por la misericordia de Dios estés en el purgatorio"97. "Que Dios por su misericordia se lo perdone al que no los dejó llevar al debido suplicio"98 [a don Quijote que liberó a los galeotes]. "Los que reciben son inferiores de los que dan, y así es Dios sobre todos, porque es dador sobre todos, y no pueden corresponder las dádivas del hombre a las de Dios con igualdad, por infinita distancia, y esta estrecheza y cortedad en cierto modo la suple el agradecimiento"99. "Porque ¡vive el Dador!"100. "¿Por qué no deja de ser bruja, y se vuelve a Dios, pues sabe que está más pronto a perdonar pecados que a permitirlos? [...]. La costumbre del vicio se vuelve en naturaleza [...]. Y ni se acuerda [el alma] de los temores con que Dios la amenaza ni de la gloria con que la convida [...]. Dejándose estar sumida en la profunda sima de su miseria, no quiere alzar la mano a la de Dios, que se la está dando por sola su misericordia para que se levante"101. Dice la bruja Cañizares: "Así que siempre mis pensamientos han de ser malos; con todo esto sé que Dios es bueno y misericordioso y que Él sabe lo que ha de ser de mí, y basta"102. "Para guarecer de estos males, la gran misericordia de Dios ha de ser la maestra, la que ha de aplicar la medicina"103. El alma, aun-

$91 R D$, II, 353. Resuena aquí un texto de san Pablo: "¿Quién será el fiscal de los elegidos de Dios? Dios, el que perdona. ¿Quién será el que condene? Cristo Jesús, el que murió, o, mejor dicho, resucitó, el mismo que está a la derecha de Dios, el mismo que intercede en favor nuestro" ( $\mathrm{Rm} \mathrm{8,33-34).}$

${ }^{92} R V, 84$.

$93 Q M$, II, 16, 823.

$94 Q M$, II, 40, 1042.

$95 Q M$, II, 42, 1061 .

96 ERASMO, Educación del príncipe cristiano, en Obras escogidas, edición y traducción de Lorenzo Riber, Aguilar, Madrid $1964^{2}$, p. 331.

$97 Q M$, II, 55, 1180.

$98 Q M$, I, 29, 378.

99 QM, II, 58, 1205.

$100 R C, 202$. Fórmula de juramento propia de gente baja.

$101 C P, 599$.

$102 C P, 600$.

103 PS, IV, 10, 689. 
que esté a punto de expirar, "no ha de de dejar esperar su remedio, porque sería agraviar a Dios, que no puede ser agraviado, poniendo tasa y coto a sus infinitas misericordias"104. Don Quijote despierta del profundo sueño y grita: "¡Bendito sea el poderoso Dios, que tanto bien me ha hecho! En fin, sus misericordias no tienen límite, ni las abrevian ni impiden los pecados de los hombres". La sobrina le pregunta: "¿Qué misericordias son estas, o qué pecados de los hombres". Y él contesta: "Las misericordias, sobrina, son las que en este instante ha usado Dios conmigo, a quien , como dije, no las impiden mis pecados. [Se arrepiente de haber leído "los detestables libros de las caballerías" y quisiera compensar "leyendo otros que sean luz del alma"]. Ya me son odiosas todas las historias de la andante caballería; ya conozco mi necedad y el peligro en que me pusieron haberlas leído; ya, por misericordia de Dios escarmentando en cabeza propia, las abomino"105. Hasta tres veces invoca don Quijote las misericordias de Dios en su lecho de muerte.

Estamos en el meollo de la Sagrada Escritura, el Dios de amor y misericordia ${ }^{106}$. En los evangelios sinópticos aparece doce veces el verbo griego splagchnízomai, que suele traducirse por "tener compasión o misericordia"; pero literalmente significa "sentir una conmoción visceral", "conmovérsele las entrañas". Así reaccionaba Jesús ante el sufrimiento de la gente107, "el cual pasó haciendo el bien y curando a los oprimidos por el diablo porque Dios estaba con Él" (Hch 10, 38). "Dios es amor" (1Jn 4, 8), amor creador, que nos sostiene en el ser y nos impulsa a hacer el bien; amor del que pueden participar todos los hombres colaborando en la obra de la creación, que sigue abierta. Y es que lo más profundo de mi "yo" no soy yo sino Dios. "Tú estabas más adentro que lo más íntimo de mí mismo y más alto que lo más alto de mí mismo"108. Por eso puede participar el hombre de este amor que crea y recrea el mundo, y si lo hace se convierte en providencia de Dios, su presencia entre los hombres. "Mi Padre hasta el presente sigue trabajando, y yo también trabajo" (Jn 5,17$)$. No hay un orden social cerrado. Hay que estar creándolo contantantemente para que se ajuste cada vez más a la justicia de Dios. "Buscad primero que reine su justicia" (Mt 6, 33). Lo específico de los cristianos es que nuestro punto de referencia, nuestra estrella polar, es Jesucristo (Jn 3, 15; 19, 37), que es también amor creador y es vida,

\footnotetext{
104 PS, I, 9, 198.

$105 Q M$, II, 74, 1329-1331.

106 Benedicto XVI, Deus caritas est, San Pablo, Madrid 2006.

107 Cf. Lc 7, 13; Mc 6, 34 par; Mc 1, 41; Mt 20, 34...

108 San Agustín, Confesiones 3, 6, 11.
} 
de cuyo amor participamos ${ }^{109}$. "La prueba es que de su amor todos nosotros hemos recibido: un amor que responde a su amor" (Jn 1, 16). El amor, agápe, acabará triunfando sobre el mal y sobre la muerte (1Cor 13,13). A esto tienen que comprometerse los cristianos. Como solía decir Julián Marías: "por mí que no quede". Los textos sobre el amor y la misericordia de Dios abundan en la Sagrada Escritura. Cervantes los conocía bien y había reflexionado sobre ellos. "Salmos de David benditos, / cuyos misterios son tantos / que sobreceden a cuantos / renglones tenéis escritos"110. No hagamos de Cervantes un contemporáneo nuestro, pero hay textos suyos que disuenan con la música de la Contrarreforma.

Dios es Padre. "Dios nos ha de remediar. / [...] El Señor que nos ha hecho / no nos tiene de olvidar. / Roguémosle como a Padre"111. "Aquél que me negare ante los hombres, / de Mí será negado ante mi Padre; / y el que ante ellos a Mí me confesare, / será de mí ayudado ante el eterno / Padre mío"112. Dialogan los niños Francisquito y Juanico a punto de ser martirizados: "¡Oh cuán de molde que viene / decir aquí el Padrenuestro. / -Pues faltan los de la tierra, / bien es acudir al cielo, / do nuestra Padre se encierra. / -A un tiempo llamarélo. / -Porque todo al justo cuadre, / lo postrero que mi madre / me enseñó quiero decir, / que es bueno para el morir. / -¿Qué has de decir? [le pregunta el cadí.] / Creo en Dios Padre"113. "Vuelve, que te desafío / a tí y al infierno todo, / hecho valentón al modo / que plugo al gran Padre mío"114. "¡Padre del cielo, en cuya fuerte diestra / está el gobierno de la tierra y cielo, / cuyo poder acá y allá se muestra / con amoroso, justo y santo celo!"115.

Dios es providente, pero este atributo merece un estudio especial, dados los muchos pasajes en que aparece, $\mathrm{y}$, además, porque forma un grupo semántico con estas otras palabras: fortuna, hado, destino, astrología, naturaleza, cielo. Cervantes afirma sin ambages la Providencia de Dios. Todo está bajo sus órdenes y concurre con las causas segundas según el modelo tradicional escolástico.

Estos son los atributos de Dios, los rasgos distintivos o semas del semema "Dios" según Cervantes. Algunos se obtienen por negación de las limi-

109 Cf. MARÍAs, J., La perspectiva cristiana, Alianza, Madrid 1999, cs. 11-12, pp. 95-104, y c. 17, pp. 133-139; Marina, J. A., Por qué soy cristiano, Anagrama, Barcelona, cs. 7-8, pp. 121-152.

$110 R D, \mathrm{I}, 342$.

$111 T A, \mathrm{IV}, 144$.

$112 T A$, IV, 140. Reproduce Mt 10, 32-33.

$113 B A$, II, 304.

$114 R D$, III, 359.

115 TA, I, 116. 
taciones humanas: impecable (negación del pecado), infinito (negación de la finitud), eterno (negación del tiempo). Otros por elevación al sumo grado de las cualidades humanas: Creador o Hacedor, el Bien que deseamos, omnipotente, la Verdad, la Sabiduría, el Altísimo, el Soberano, el Señor, presente en todo "por potencia, esencia y presencia", la Justicia, Juez, Médico, la Misericordia, Padre, Providencia. En Él todos los atributos son iguales, "aunque a nuestro modo de ver más resplandece y campea la misericordia que la justicia".

Una observación: las fichas no son los textos. Puede ser que alguna se haya traspapelado o que por descuido no se haya recogido algún pasaje. Esta visión cervantina de Dios como misericordia, bondad, amor y Padre coincide con su visión moral del hombre, en la que destacan sobre toda otra virtud la misericordia, la bondad, la comprensión y la caridad. Con los textos sobre la caridad se pueden escribir varios capítulos.

Me extraña la ausencia de dos atributos fundamentales en la época de Cervantes: Juez y Majestad. Juez lo usa dos veces con algunos textos más sobre la justicia. En una de ellas usa la palabra sin más, en la otra advierte que en el supremo tribunal hay un Padrino, Jesucristo, y un Juez, que es Dios, en el que hay que confiar. Acude a la misericordia, no a la severidad. En los textos en los que Cervantes habla del juicio particular y del universal, que incluiré en las postrimerías, brilla su moderación. Si recordamos lo que se predicaba por esos púlpitos y en los libros espirituales de la Contrarreforma sobre aquel día espantoso, en que el sol se oscurecerá, las estrellas caerán y todo arderá en un fuego infernal, y en el que los hombres, empavorecidos, resucitarán en el Valle de Josafat, "al son de trompeta, quisque con su maleta", como dice Berceo, para dar cuenta pública de sus pecados, la sobriedad de Cervantes no tiene precio. No participaba de la exaltación contrarreformista. No olvidemos que era una de las meditaciones obligadas de los Ejercicios espirituales. El Dios del terror -la cólera de Dios-, del juicio y del castigo, tan presente ya en los Padres del desierto, está ausente en Cervantes.

La palabra majestad aparece ya en Berceo: "Apareciól la Madre del Rei de magestad"116 A finales del siglo XV y principios del XVI, "la Corona era ya conocida como señoría mayor en todo el ámbito peninsular y mediterráneo: por eso empieza a aparecer en los documentos el término Majestad, que excede en mucho al de Alteza hasta entonces de uso corriente. Para expresarlo en términos más próximos a nosotros, esa Majestad soberana

116 Berceo, Milagros de Nuestra Señora, edición de A. G. Solalinde, Espasa-Calpe, Madrid $1952^{4}$, XXI, estrofa 529, p. 126. 
significaba una autoridad que sólo a Dios, de quien depende, reconoce como superior"117. La palabra pasó pronto a los autores espirituales, que comenzaron a hablar de "su divina Majestad". La palabra la usa alguna vez Cervantes aplicada a los reyes de la tierra, nunca referida a Dios. Es expresión muy abundante en las obras de san Ignacio de Loyola y en las de santa Teresa de Jesús. Ante Él hay que caer de rodillas, rostro en tierra. A Él se le debe reverencia, honor, acatamiento y obediencia. La arquitectura del Barroco, la suntuosidad de los retablos, el oro recargado de las casullas, la pompa de las católicas ceremonias, la solemnidad de las procesiones, en las que todo estaba reglamentado, con sus hileras de frailes con sus cruces o portando calaveras o royendo huesos... Todo estaba pensado para expresar la grandeza, la magnificencia, la sublimidad de su divina Majestad y la miseria y mezquindad del hombre. Hacer a Cervantes campeón de la Contrarreforma, como a veces se ha dicho, no tiene sentido. Hay silencios que hablan.

\subsection{La Trinidad}

\subsubsection{El dogma}

El español Antonio, un soldado español de la Contrarreforma, instruye a su mujer Ricla, bárbara, nacida en las tierras septentrionales de Europa, en la fe cristiana y la bautiza. "Creo, dice ella, en la santísima Trinidad, Dios Padre, Dios Hijo y Dios Espíritu Santo, tres personas distintas, y que todas tres son un solo Dios verdadero, y que, aunque es Dios el Padre, y Dios el Hijo, y Dios el Espíritu Santo, no son tres dioses distintos y apartados, sino un solo Dios verdadero [...]. Creo todo lo que tiene y cree la Santa Iglesia Católica Romana, regida por el Espíritu Santo [...]. Díjome grandezas de la siempre Virgen María, tesoro del Padre, relicario del Hijo y amor del Espíritu Santo"118. A Auristela y a Periandro [Sigismunda y Persiles] los penitenciarios, "con razones sobre la razón misma, bosquejaron el profundísimo misterio de la Santísima Trinidad"119.

Decir que aquí hay "el reconocible bosquejo de una doctrina sobre la Trinidad inevitablemente heterodoxa", como dice Carlos Alberto Morey-

117 SUÁREZ, L., "Cohesión e ideal sociales en la España de los Reyes Católicos", en Arbor, 178 (2004), p. 7.

118 PS, I, 6, 176-177.

119 PS, IV, 5, 657. 
$\mathrm{ra}^{120}$, no tiene fundamento ninguno. Cervantes presenta a Ricla como cristiana católica. Confiesa su fe en la Trinidad, en la Santa Iglesia Católica Romana, en el Papa, "vicario y visorrey de Dios en la tierra", en las grandezas de la Virgen María. Síntesis parecidas de la fe hay en novelas y comedias de la época. Los peregrinos se dirigen desde las tierras nórdicas, en las que la fe tiene "algo de quiebra"121 (Reforma protestante), a Roma, cima de la fe, no sin antes pasar por Portugal y España, donde la fe está en su punto, "rincón del mundo donde está recogida y venerada la verdadera verdad de Cristo" 122. Quizá Cervantes seguía pensando en una próxima unidad de los cristianos. Motivos parecidos existen también en La española inglesa. Cervantes afirma la fe de la Iglesia en la Trinidad sin entrar en disquisiciones. Se necesita ser más que hombre para comprenderlo, sobre todo si lo explican con la filosofía aristotélica. "Con razones sobre la razón misma". ¿Qué clase de razones son éstas? Razones que exceden la inteligencia, ininteligibles. ¿Inútiles? "Y porque no hay razones humanas que sean bastantes para persuadir y para entender esto, es menester que el entendimiento humano se sojuzgue y someta a la obediencia de la fe"123.

Conviene tener presentes unos cuantos datos muy peculiares de la situación española. En España existían tres religiones o culturas: cristianismo, islamismo y judaísmo. Demos al olvido su convivencia pacífica durante la Edad Media. Dos de ellas, islamismo y judaísmo, eran antitrinitarias. Consideraban a los cristianos politeístas. Los judíos encontraban razones en el mismo lenguaje. Ellos decían "el Dio en lugar de Dios, que les parecía un plural adecuado al trinitarismo cristiano"124. Los cristianos decían Dios, del nominativo Deus, una de las poquísimas palabras procedentes del nominativo, pero su terminación sonaba a plural. A esto se añadía que en textos del siglo XIII, al hablar de los dioses paganos, era usual la forma los dios. El

120 Cit. por Carlos Romero Muñoz en su edición de Los trabajos de Persiles y Sigismunda, apéndice XXXIII, p. 748. Las dos citas sobre la Trinidad pertenecen a dos símbolos de fe, que aparecen en el Persiles. Sobre ellos he escrito en "La fe en Cervantes", en Religión y Cultura, 52(2006), pp. 36-44.

121 PS, IV, $12,703$.

122 PS, III, 11, 547-548.

123 VALDÉs, J. de, Diálogo de doctrina christiana y el Salterio traducido del hebreo en romance castellano, transcripción, introducciôn y notas de Domingo Ricart, Universidad Nacional Autónoma, México 1964, p. 30.

124 LAPESA, R., Historia de la lengua española, Gredos, Madrid $1980^{8}$, c. 16, pp. 524-525. En las Glosas Silenses aparece una vez la forma dio. Cf. LAPESA, R., Léxico hispánico primitivo (siglos VIII al XII), Fundación Ramón Menéndez Pidal / Real Academia Española, Madrid 2003, s. v. dio. 
reproche de politeístas a los cristianos por los judíos tenía su fundamento. Más tarde se introdujo el plural analógico los dioses ${ }^{125}$.

A los conversos se los acusaba de no creer, como judíos, en la Trinidad. El doctor Villalobos, médico judío converso, se pone en escena a sí mismo en un diálogo con su señor el duque de Alba, que le reprocha "que, como todos sus congénéres, es rebelde al dogma de la Santísima Trinidad"126. Era de esperar la reacción de los conversos. Para alejar el impertinente moscardón de las sospechas, creyeran o no, hacían alarde de fe en la Trinidad. Es lo que Américo Castro ha llamado "estilo trinitario", observado por él en Diego de Valera, Colón, Las Casas y Andrés Laguna, todos ellos conversos. Las Casas cuenta que Colón "cuasi en cada cosa que hacía y decía o quería comenzar a hacer, siempre anteponía: en el nombre de la Santísima Trini$d a d "$. Para integrarse en la sociedad de los cristianos viejos, para redimirse socialmente, el primer paso "oficial" era construir una capilla en honor de la Santísima Trinidad"27. ¿No es esto afinar demasiado? "Nos preguntamos: aunque algunos neocristianos del XV, para mostrar su agresivo cristianismo, recalcasen su creencia en la Trinidad, ¿por qué un cristiano sincero no puede mostrar públicamente su adhesión a un dogma central de su fe sin ser tildado de converso?"128. Los testamentos y otros muchos documentos comenzaban con la fórmula In nomine sanctae et individuae Trinitatis, Patris el Filii et Spiritus Sancti.

Los musulmanes eran también antitrinitarios y lo eran, en consecuencia, los moriscos. Quizá alude a ello Cervantes al constatar lo imposible que resultaba convencerlos de las verdades de la religión católica ${ }^{129}$. En las cajas de plomo del Sacromonte se modificó el dogma de la Trinidad a fin de que fuera menos difícil de aceptar por los moriscos: "No hay otro Dios, sino Dios, y Jesús, espíritu de Dios", fórmula que llegó a usar el arzobispo de Granada ${ }^{130}$.

125 Cf. Corominas, J.- Pascual, J. A., Diccionario crítico etimolígico castellano e hispánico, Gredos, Madrid 1950, t. II, s.v. Dios.

126 Bataillon, M., "La pícara Justina", en Pícaros y picaresca, Taurus, Madrid 1969, p. 161.

127 Cf. CAStro, A., Cervantes y los casticismo españoles, Alianza, Madrid 1974, pp. 203. 206. 210 .

128 Asensio, E., La España imaginada de Américo Castro, Crítica, Barcelona 1992, c. 2, p. 95.

${ }^{129} Q M, \mathrm{I}, 33,418$. Léase la nota a este pasaje.

130 Cf. CASTRo, A., Cómo veo ahora el Quijote, en Cervantes SAAvedra, Miguel de, El ingenioso hidalgo don Quijote de la Mancha, Magisterio Esañol, Madrid 1971, estudio preliminar de, t. I, p. 29. 
Todo esto explica que los españoles tuvieran fama de antitrinitarios, lo que los italianos llamaban malignamente peccadiglio di Spagna ${ }^{131}$. Y explica que el español, a veces, quisiera dejar las cosas bien sentadas ante el posible husmeo del siempre temeroso Santo Oficio. Como explica también que aquí arraigase la devoción a la Santísima Trinidad como defensa contra la herejía que estaba en casa. Antes de entrar en batalla, el obispo don Jerónimo (don Jerome), que acompañaba como guerrero al Cid, decía la misa en honor de la Trinidad. La devoción a la Santísima Trinidad es característica de san Ignacio de Loyola ${ }^{132}$.

\subsubsection{Expresiones coloquiales}

Los textos que agrupo aquí pertenecen al conglomerado enorme de frases, refranes y expresiones del lenguaje coloquial, tan abundante en Cervantes. Su lugar estaría mejor en un apartado dedicado exclusivamente a ellas, pero si las reúno aquí es porque las veo como algo más que expresiones familiares.

"Vete en paz y aquesta tarde / ven por tus firmas, Hazén. / -La Trinidad toda os guarde"133. Hazén es un renegado que quiere volver a España. Anda recogiendo firmas que atestigüen su buen comportamiento con los cristianos para facilitar su reconciliación. Vive entre moros antitrinitarios y cristianos trinitarios. Pudo decir "Dios os guarde", la expresión más usual, de origen árabe ${ }^{134}$. Al mencionar a la Trinidad, quiere indicar que vive ya en el mundo al que aspira, que participa de sus creencias. Para mostrar que se es cristiano nada mejor que emplear el distintivo trinitario. Realza, además, el sustantivo pospóniendole el indefinido "toda". Hay algo más que una expresión del lenguaje familiar en las palabras de Hazén.

El rey don Fernando de Aragón construyó en la ciudad de Gaeta, en el reino de Nápoles, un templo y un monasterio a la Trinidad, invocada por los navegantes que lo veían desde alta mar y muy visitado por ellos. "Dios te guíe y la Peña de Francia, junto con la Trinidad de Gaeta, flor, nata y espuma de los caballeros andantes", dice Sancho mientras da soga a don Quijote, que baja a la cueva de Montesinos ${ }^{135}$. La Peña de Francia es Nuestra

\footnotetext{
c. 1, p. 60 .

131 Cf. Bataillon, M., Erasmo y España, Fondo de Cultura Económica, México $1966^{2}$,

132 Cf. RICARD, R., "Situación de san Ignacio dentro de la espiritualidad española", en Estudios de literatura religiosa española, Gredos, Madrid 1964, pp. 148-149.

$133 B A$, I, 280.

134 LAPESA, R., Historia de la lengua española, edic. cit., c. 5, pp. 156-157.

${ }^{135} Q M$, II, 22, 890. Léase la nota a este pasaje.
} 
Señora de la Peña de Francia. Sancho, montado sobre Clavileño, reincide en la invocación: "Ea, pues, Dios me ayude y la Santísima Trinidad de Gaeta"136. En estas jaculatorias de Sancho, Cervantes satiriza las devociones populares, propensas a la deformación y a confusiones y errores. En las palabras de Sancho, Dios y la Trinidad son cosas distintas, objeto de dos invocaciones ${ }^{137}$. ¿Que idea tenía el pueblo de este misterio? Hay otros testimonios populares de esa época, en que se hace la misma distinción o se la hace hermana de la Virgen. En 1611, el morisco Miguel Manacho, expulsado de España, se dirigió al duque de Osuna y entre otras cosas le decía: "Mi mujer cayó enferma y pidió confesión cuatro veces, y no hubo orden de podérsela dar, y ella se abrazó con Dios y la Santísima Trinidad y murió" 138 . También padecían confusiones los habitantes de un pueblo del Barroso, quienes, según cuenta fray Luis de Granada, salieron a recibir al arzobispo de Braga cantando muy devotamente: "Bendita sea la Santísima Trinidad, hermana de Nuestra Señora" 139 .

\subsection{Ateísmo teórico y práctico}

La explicación natural de los fenómenos atmosféricos, la exaltación del hombre, el valor absoluto atribuido a la naturaleza llevaron a algunos pensadores a prescindir de todo principio sobrenatural. En Francia se dio el movimiento de los libertins. En España resultaba más difícil expresarse en alta voz sobre estas materias. Se habla del ateísmo del doctor López Illescas, estudiado por Ángela Selke de Sánchez ${ }^{140}$. Sobre el alcance que tienen las acusaciones de ateísmo que se lanzaban como injuria los hombres del siglo XVI, sobre los razonamientos muy de su época, así como sobre los problemas que plantea la lectura de tales textos al historiador no se deben olvidar las páginas que escribió Lucien Fèbvre a propósito del supuesto ateísmo de Rabelais ${ }^{141 .}$

$136 Q M$, II, 41, 1046.

137 Cf. Moreno BÁez, E., "Perfil ideológico de Cervantes", en Suma cervantina, editada por J. B. Avalle-Arce y E. C. Riley, Tamesis Bookss, London 1973, p. 250.

138 CASTRo, A., "El gran duque de Osuna", en Teresa la Santa y otros ensayos, Alfaguara, Madrid-Barcelona 1972, p. 225.

139 Cit. por CARO BAROJA, J., Las formas complejas de la vida religiosa. (Religión, sociedad y carácter en la España de los siglos XVI y XVII), Akal, Madrid 1978, c. 14, p. 330.

140 Cf. Bataillon, M., ib., c. 9, pp. 485-486; SElKe DE SÁnCHEZ, A., “¿Un ateo español en el siglo XVI? Las tentaciones del doctor Juan lópez de Illescas”, en Archivum, 7 (1958), pp. 25-47.

141 Cf. FèBVRe, L., Le problème de l'incroyance au XVI siècle, Albin Michel, Paris 1975, l. 1, en especial c. 2, pp. 126-138; CARo BAROJA, J., ib., c. 1, pp. 27-32 y c. 8, pp. 197-207, 
En Cervantes no se plantea el problema. Hay algunas alusiones puramente retóricas. "Si va a decir verdad, / yo ninguna cosa creo", dice un turco renegado. "Fino ateísta te muestras" 142 , le responde un renegado cristiano. "Bien parece que ignoráis / cómo para mí no hay Dios", dice doña Ana al P. Cruz, y añade: "No hay Dios, digo, / y mi malicia / hace, con mortal discordia, / que esconda misericordia / el rostro, y no la justicia"143. Se niega que hay Dios, pero acto seguido se desconfía de su misericordia y se teme su justicia. A lo que el P. Cruz responde: Dixit insipiens in corde suo: non est Deus, "piensa el necio: no hay Dios" (Sal 14 [13], 1). "Poco me curo de Cristo; / de Mahoma no hay que hablarme; / es mi dios mi brazo solo, / y mis obras, mis penates. / -Dios te salve y te contente. / ¡Salutación enfadosa! / Sálveme mi brazo a mí, / y conténteme mi fuerza"144.

\section{EL HOMBRE}

No intento escribir sobre el hombre en las obras de Cervantes. Mi punto de vista es exclusivamente religioso. Dejo a un lado numerosas consideraciones sobre la vida humana, expuestas unas veces en fórmulas doctrinales y otras, las más frecuentes, en la ficción literaria. De Cervantes se pudiera extraer un buen volumen de sentencias y discursos sobre el hombre, que haría de él una especie de moralista a lo Montaigne. Cervantes era novelista, dramaturgo y poeta, no filósofo ni teólogo; pero estaba bien informado sobre la cultura de su tiempo y de ella partía en sus elaboraciones artísticas. Muchas afirmaciones de El pensamiento de Cervantes, de Américo Castro, han sido invalidadas, pero sigue siendo un libro importante para comprender la cosmovisión cervantina y su inmersión en el contexto intelectual, y por sus muchas observaciones atinadísimas sobre teoría literaria ${ }^{145}$.

donde se recuerdan entre otros textos interesantes las palabras del jesuita belga Lessius: conocemos mejor a los ateos antiguos que a los modernos, porque estos no hablan por miedo a las leyes; GREEN, Otis H., España y la tradición occidental, Gredos, Madrid 1969, t. III, c. 7, pp. 209-218.

$142 G S, 1,368$.

$143 R D$, II, 352.

$144 C C$, III, 261-263.

145 Cf. Peña, A., Américo Castro y su visión de España y de Cervantes, Gredos, Madrid 1975; Asensio, E., La España imaginada de Américo Castro, edic. cit.; Morón, C., Para entender el Quijote, Rialp, Madrid 2005, c. 10, pp. 295-340. 


\subsection{Creación y fin del hombre}

El hombre fue creado por Dios y para Dios fue hecho. Es un mundo abreviado, compendio de la creación, microcosmos, que participa del mundo visible y del invisible. Subiendo por la escala de la belleza, los filósofos gentiles llegaron hasta "la primera causa de las causas", pero "lo que más los admiró y levantó la consideración, fue ver la compostura del hombre, tan ordenada, tan perfecta y tan hermosa, que le vinieron a llamar mundo abreviado; y así es verdad, que, en todas las obras hechas por el mayordomo de Dios, Naturaleza, ninguna es de tanto primor ni que más descubra la grandeza y sabiduría de su Hacedor, porque en la figura y compostura del hombre se cifra y cierra la belleza que en todas las otras partes de ella se reparte"146. Los ángeles malos dejaron vacías las sillas del cielo. Los penitenciarios, al exponerles la doctrina católica a Auristela y a Periandro, les dijeron "el medio que Dios tuvo para llenar estos asientos, criando al hombre, cuya alma es capaz de la gloria que los ángeles malos perdieron. Discurrieron por la verdad de la creación del hombre y del mundo" 147 .

La idea de crear al hombre para llenar las sillas que Lucifer y sus compañeros dejaron vacías está ya en Juan de Valdés. "Lucifer quiso ser semejante a Dios, por lo cual Dios echó del cielo a él y a sus compañeros [...]. Hecho esto, viendo Dios que aquellas sillas que los ángeles malos habían perdido estaban vacías, quiso criar el linaje humano, para que las poseyesen aquellos que le fuesen obedientes"148. Mucho antes, San Agustín escribió que Dios redimió al hombre para ocupar los puestos dejados vacíos por los ángeles rebeldes. De este modo, la Jerusalén celeste no se verá disminuida en la muchedumbre de sus ciudadanos, "y aun quizá reinará con más numerosa muchedumbre"149. Y si san Agustín lo dijo, es seguro que tiene que haber muchos más textos en la tradición cristiana. Por esto, es completamente disparatado el esoterismo en que se envuelve Carlos Alberto Moreyra, al decir que la idea de que Dios creó al "hombre como un medio es capital en la concepción de conocidos antitrinitarios de entonces" 150 .

146 LG, IV, 439. Cf. Rico, F., ib., edic. cit., pp. 139-143.

$147 \mathrm{PS}, \mathrm{IV}, 5,657$. Léase la nota a este pasaje.

148 VALDÉs, J. de, $i b$., edic. cit., p. 103.

149 San Agustín, Enquiridion, 29 y 62; cf. ÍD., La ciudad de Dios 22, 1, 2.

150 Cit. por ROMERo MUÑOz, C., en su edición de Los trabajos de Persiles y Sigismunda, Apéndices, XXXIII, p. 748. Cf. VeGA, J., " La fe en Cervantes", en Religión y Cultura, 52 (2006), pp. 40-41. 
Recordemos la creación de la mujer: "Cuando Dios crió a nuestro primero padre en el Paraíso terrenal, dice la divina Escritura que infundió Dios sueño en Adán y que, estando durmiendo, le sacó una costilla del lado siniestro, de la cual formó a nuestra madre Eva; y así como Adán despertó y la miró, dijo: Esta es carne de mi carne y hueso de mis huesos; y Dios dijo: Por esta dejará el hombre a su padre y madre, y serán dos en una carne misma"151. No olvidemos los textos dados en los atributos de Dios en los que aparece Dios como Creador, muy especialmente del hombre.

$\mathrm{Y}$ ¿qué decir del fin para el que el hombre fue creado? El perro Berganza se quedó un día a la puerta del aula del colegio de los jesuitas de Sevilla, donde estudiaban los dos hijos de su amo, y así otros muchos días, "mirando de hito en hito al maestro que en la cátedra leía [...]. Cómo les pintaban la fealdad y horror de los vicios, y les dibujaban la hermosura de las virtudes, para que, aborrecidos ellos y amadas ellas, consiguiesen el fin para que fueron criados"152. Es el principio y fundamento de los Ejercicios

$151 Q M$, I, 33, 424. Cf. Gn 2, 21-24. En la Biblia, es Adán el que dice los dos enunciados. Remito a la nota 56 de este estudio.

$152 C P, 563$. Cf. Rodríguez MARín, F., en Cervantes, Novelas ejemplares, edición, prólogo y notas de, Espasa-Calpe, Madrid 1965, t. II, pp. 243, n.10, cree que en este elogio que Cervantes hace de los jesuitas expresa su experiencia de discípulo. También lo cree RIQUER, M. de, Para leer a Cervantes, Acantilado, Barcelona 2003, c. 2, pp. 36-37. Fernández ÁlvaREZ, M., Cervantes visto por un historiador, Espasa Calpe, Madrid 2005, c. 1, pp. 48-49, da por hecho que Cervantes fue alumno de ellos. CANAVAGGIo, J., en cambio, lo niega, Cervantes, Espasa Calpe, Madrid 1987, c. 1, p. 35. BLAsco, J., Cervantes: un hombre que escribe, Difácil, Valladolid 2006, c. 3, p. 52, cree que el núcleo familiar de los Cervantes seguía en Alcalá mientras el padre Rodrigo estaba en Sevilla. Si su hija Andrea fue con él, también pudo ir Miguel, pero no hay documentación que lo pruebe. Conjeturas y conjeturas. Los cirujanos solían ser los barberos. No es posible que el hijo de un cirujano -"hombre que hace ligaduras y cura otras enfermedades $(J D, 69)$-, que vivió siempre con gran estrechez, cursara sus estudios en el colegio adonde acudía la elite de Sevilla. ¿Y si este que dicen elogio fuera en realidad un elogio solapado y retorcido, una ironía, que dice lo contrario de lo que parece decir? Los enseñaban a alejarse de los vicios y a seguir el camino de la virtud. ¿Sólo eso? De un músico se dice que "es muy buen cristiano, y hidalgo de solar conocido. ${ }_{-}$Calidades son bien necesarias para ser buen músico!" $(R M, 176)$. "Para repúblicos del mundo no los hay tan prudentes en todo él" $(C P, 564)$. ¿No estará aludiendo aquí a los compromisos mundanos de la Orden? Al final, con astucia enrevesada, "ordenaron a mis amos que no me llevasen más al estudio". ¿Razón? "Desta quietud me vino a quitar una señora que, a mi parecer, llaman por ahí razón de estado, que cuando con ella se cumple, se ha de descumplir con otras razones muchas" ( $C P$, 565). En nota a este pasaje dice el editor y da bibliografía sobre la materia: "La razón de esta$d o$ era el conjunto de reglas y preceptos de carácter político y social para mantener el poder". Aquí está lexicalizada y significa 'cuestión de reglamento', 'obligación', 'razón de fuerza mayor'. ¡La razón de estado, tan defendida por los jesuitas! Cuando se cumple con ella, se quebrantan otras muchas. Está claro el sentido peyorativo. No, Berganza y Cipión no hacen elogios, descuartizan a todas las clases sociales. Este elogio hay que leerlo en negativo y descodificar lo que en él está oculto. Cervantes no se vuelve a acordar de los jesuitas. Ni en la lista 
espirituales: "El hombre es criado para alabar, hacer reverencia y servir a Dios nuestro Señor, y mediante esto salvar su ánima"153. Los catecismos de la época decían: el hombre fué creado "para servir a Dios en esta vida y después gozarle en la eterna". Cervantes tiene numerosos textos sobre uno y otro tema. De servir a Dios en esta vida hablaré aquí. Un estudio sobre las postrimerías es el lugar adecuado para exponer la visión beatífica de Dios.

\subsection{La condición humana}

Hay en la naturaleza humana inclinaciones al mal, que hunden sus raíces en las capas más recónditas y se agarran tercamente a su tierra. Pero hay también tendencias hacia el bien, más profundas y eficaces que sus contrarias. El pastor Lauso se lamenta del mundo mentiroso, de las vanas imaginaciones, del caos, del desasosiego, de la Babilonia cortesana, y suspira por la vida rústica y el pastoral albergue. Es el viejo tema del menosprecio de corte y alabanza de aldea. "La humana condición, flaca, doliente, / en caducos placeres ocupada, / do busca, sin hallarle, algún reposo"154. La condición humana exige la risa, el pasatiempo y la recreación. "No es posible que esté continuo el arco armado, ni la condición y flaqueza humana se puede sustentar sin alguna lícita recreación"155. "Aunque parezca que cuentan imposibles, a mayores peligros está sujeta la condición humana"156.

A veces asoma la consideración ascética de renunciamiento a las pompas y vanidades. Sancho, a lomos de Clavileño, no resiste la tentación de atisbar lo que se ve desde las alturas. "Miré hacia la tierra, y parecióme que toda ella no era mayor que un grano de mostaza, y los hombres que andaban sobre ella poco mayores que avellanas"157. "Después que bajé del cielo,

de autores del Canto de Calíope, en La Galatea, ni en la del Viaje del Parnaso figuran autores jesuitas, y no se hubiera olvidado de ellos si como dicen tuvo por maestro al P. Acevedo, autor de piezas teatrales. Habrá que leer este texto a la luz de lo que Cervantes dice sobre los religiosos y de lo que cuenta el P. Juan de Mariana en su Discurso de las cosas de la Compañía. Su ironía dardea contra el clero en muchas de sus obras.

153 San IgNACIO DE LOYOLA, "Ejercicios espirituales", en Obras completas, edición del P. Ignacio Iparraguirre, BAC, Madrid 1952, n² 23, p. 161. Cf. GreEN, Otis H., ib., edic. cit., t. II, c. 4 , pp. $178-180$.

${ }^{154} L G, I V, 407$. Léase la nota a este pasaje.

$155 Q M, I, 48,609$. Lo del arco tenso y relajado era un tópico literario. Léase la nota a este pasaje.

156 PS, II, 5, 310.

$157 Q M$, II, 41, 1053. Léase la nota a este pasaje. CASTRo ha señalado un pasaje de uno de los evangelios apócrifos del Sacromonte: "El ángel Gabriel desde el primer cielo mira hacia 
y después que desde su alta cumbre miré la tierra y la vi tan pequeña, se templó en parte en mí la gana que tenía tan grande de ser gobernador; porque ¿qué grandeza es mandar en un grano de mostaza, o qué dignidad o imperio el gobernar a media docena de hombres tamaños como avellanas, que a mi parecer no había más en toda la tierra?"158. No era desconocida de los espirituales esta manera de comparar la tierra y el hombre con las inmensidades del universo. "¿Es más que un breve punto / el bajo y torpe suelo, comparado / con ese gran trasunto, / do vive mejorado / lo que es, lo que será, lo que ha pasado?"159. Es posible que estos versos de fray Luis, tan querido de Cervantes, resuenen en estos textos del Quijote, como también algún eco de la oda $A$ Felipe Ruiz, "Cuándo será que pueda", como señaló A. Castro. Pero el punto de partida es el Sueño de Escipión ${ }^{160}$, muy conocido en la Edad Media con el comentario de Macrobio, con sus muchas derivaciones posteriores. Pascal llevará esta contemplación al máximo viendo al hombre entre dos infinitos, el mundo infinitamente grande de los astros y el infinitamente pequeño de los insectos.

La condición humana está depravada, pero no está corrompida en su raíz. El hombre fue creado en bondad y, a pesar de todo, sigue siendo bueno. No todo está perdido. Por muy general que parezca el naufragio, siempre hay buenos. "Veníos con nosotros, que, aunque somos gitanos, no lo parecemos en la caridad [...]. Llegóse a él Andrés y otro gitano caritativo -que aun entre los demonios hay unos peores que otros, y entre muchos malos hombres suele haber alguno bueno-"161. Cervantes no culpa a Dios de la maldad de los hombres. Por no culpar, ni al demonio. Nosotros somos los culpables. La naturaleza humana salió perfecta de las manos de Dios, creada en bondad, como todas las demás criaturas según se lee en el capítulo I del Génesis. Nosotros con nuestros deseos desordenados agravamos la enfermedad contraída por el pecado original, que sólo se curará en la medida en que corrijamos nuestras concupiscencias. "Todos deseaban, pero

la tierra, y la ve tamaña como un grano de mostaza sobre la mano derecha de un ángel" (Cómo veo ahora el Qijote, en Cervantes SAAVEDRA, Miguel de, El ingenioso hidalgo don Quijote de la Mancha, edic. cit., t. I, p. 73).

$158 Q M$, II, 42, 1056. Léase la nota a este pasaje.

159 LEÓN, fray Luis de, Noche serena, en Poesía completa, edición de José Manuel Blecua, Gredos, Madrid 1990, vv. 36-40, pp. 183-184. Cf. SAlazAr Rincón, J, Fray Luis de León y Cervantes, Ínsula, Madrid 1980.

160 CícRón, De republica VI, 16. Luciano de Samosata enseñaba a fijar la mirada en el gran Todo y desdeñar la miseria de esta tierra, porque Grecia no mide "más de cuatro pulgadas" y un trozo del Peloponeso no "es mayor que una lenteja". Cf. CASTRO, A., "La estructura del Quijote", en Hacia Cervantes, Taurus, Madrid $1960^{2}$, pp. 288-289

161 GI, 80 . 
a ninguno se le cumplían sus deseos: condición de la naturaleza humana, que, puesto que [aunque] Dios la crió perfecta, nosotros, por nuestra culpa, la hallamos siempre falta; la cual falta siempre la ha de haber, mientras no dejáremos de desear" 162 .

En Cervantes no hay amargura ni resentimiento por mucho que la vida le haya zamarreado. Sabe descubrir la luz riente que sale del fondo de la noche. Cuando sume a un personaje en el abismo de sus miserias, en esa misma lobreguez clarean los bermellones de la aurora. Nunca la maldad es absoluta. "La compasiva de Maritornes" le ofreció a Sancho un vaso de agua, mas, al beberlo, "rogó a Maritornes que se le trujese de vino, y así lo hizo ella de muy buena voluntad, y lo pagó de su mesmo dinero: porque, en efecto, se dice della que, aunque estaba en aquel trato, tenía unas sombras y lejos de cristiana"163. Don Quijote aconseja a Sancho que tenga misericordia con el culpable en su gobierno, como sujeto "a las condiciones de la depravada naturaleza nuestra, y en todo cuanto fuere de tu parte, sin hacer agravio a la contraria, muéstratele piadoso y clemente", y esto por imitar a Dios en quien resplandece más la misericordia que la justicia ${ }^{164}$. Al leer a Cervantes, no se puede dejar de pensar en el polo negativo que es el Guzmán de Alfarache, de Mateo Alemán. "Tan opuestamente sienten, piensan y hablan dos españoles nacidos a una semana de distancia, de vida análogamente desdichada y en una época de grandes acontecimientos nacionales. ¡Es para hacernos poner un poco de crítica y discernimiento en la idea de las generaciones literarias!" 165 .

162 PS, II, 4, 300. En nota a este pasaje dice el editor: "Asumiendo, una vez más, la sentencia agustiniana, C. no se limita a ilustrar una situación, un estar de determinados personajes, sino que apunta a la condición, al ser de todos los humanos". Sobre los deseos tiene expresiones de raigambre estoica: "No desees y serás el más rico hombre del mundo [...]. Porque está claro que lo que se desea es lo que falta, y el que no desea no tiene falta de nada, y, así, será el más rico del mundo" ( $P S, I V, 1,634-635)$. Léase la nota a este pasaje. Es la autarquía del sabio.

${ }^{163} Q M, \mathrm{I}, 17,202$. Sombras y lejos se oponen a lo iluminado y cercano en la pintura. La condición de judío o moro se ocultaba con luces de cristiano. De cerca y a primera vista eran cristianos, pero en lo oculto -sombras y lejos- eran judíos o moros. Al aplicarlo a cristiana, se vuelve del revés lo normal en la época. De cerca y a la luz vivía "en aquel trato", pero en el fondo tenía "unas sombras y lejos de cristiana". Léase la nota a este pasaje. Dice LEón, fray Luis de: "Conforme a lo que suelen hacer los que saben de pintura y muestran algunas imágenes de excelente labor a los que no entienden tanto del arte, que les señalan los lejos y lo que está pintado como cercano, y les declaran las luces y las sombras, y la fuerza del escorzado" (La perfecta casada, edición de Javier San José Lera, Espasa Calpe, Madrid 1992, pp. 73-74).

$164 Q M$, II, 42, 1061.

165 Alonso, A., "Cervantes", en Materia y forma en poesía, Gredos, Madrid 1960, p. 144. 


\subsection{El cuerpo}

Don Quijote presenta su mano a Maritornes: "No os la doy para que la beséis, sino para que miréis la contextura de sus nervios, la trabazón de sus músculos, la anchura y espaciosidad de sus venas, de donde sacaréis qué tal debe de ser la fuerza del brazo que tal mano tiene"166. Descripciones de la mano hay en Pérez de Oliva, en Mal-Lara y en otros humanistas ${ }^{167}$. En la Introducción al símbolo de la fe, fray Luis de Granada contempla también lleno de admiración la compostura y trabazón del hombre, el artificio y fábrica de sus manos, pero, a diferencia de don Quijote, concluye qué tal debe ser la sabiduría y omnipotencia de Dios. En el hombre, como en el paisaje, los espirituales veían a Dios: eran cristales que transparentaban a su Creador. Pero se estaba abriendo paso otra visión de la naturaleza y del hombre, lo cual no quiere decir que los humanistas negaran a Dios. Se habla de la "belleza y agilidad" de un mozo en los deportes de carrera y esgrima. "Luego se acomodaron otros seis a la lucha, donde con mayor gallardía dio de sí muestra el mozo: descubrió sus dilatadas espaldas, sus anchos y fortísimos pechos y los nervios y músculos de sus fuertes brazos, con los cuales, y con destreza y maña increíble, hizo que las espaldas de los seis luchadores, a despecho y pesar suyo, quedasen impresas en la tierra"168. "Estando ya los bogadores asidos de las manillas de los remos, descubiertos los brazos, donde se parecían los gruesos nervios, las anchas venas y los torcidos músculos $[\ldots]^{\prime \prime} 169$.

El cuerpo es algo admirable por sí mismo. Cervantes lo contempla en su belleza, estéticamente, como los anatomistas de la época comenzaban a estudiarlo científicamente. De la misma manera, le interesa el estudio del hombre, no sólo en su dimensión religiosa. El.cuerpo, el hombre, la naturaleza habían sido huella de Dios durante muchos siglos, espejo donde se veía la gloria del Señor. Lo seguían siendo en los espirituales de los siglos XVI y XVII. Lo son, en parte, en Cervantes, que nos recuerda que por la escala de la belleza se sube a Dios. Pero había aparecido otra tendencia, de orígenes también remotos, que abandona la visión religiosa y se entrega a la experimentación, al descubrimiento de las maravillas naturales sin preocupaciones ulteriores. No se busca a Dios con el microcospio, sino el conocimiento de los tejidos. Sobrevino el "desencantamiento del mundo" (Weber). La

\footnotetext{
$166 \mathrm{QM}, \mathrm{I}, 43,556$.

167 Cf. CAStro, A., El pensamiento de Cervantes, edic. cit., c. 7, p, 382, n. 130.

$168 P S, \mathrm{I}, 22,269-270$

169 PS, II, 10, 348.
} 
ciencia, tan magnífica en sus descubrimientos, nos ha permitido conocer mejor nuestros mecanismos biológicos; pero ha trivializado el sentido de la existencia humana y nos ha convertido en un animal más, cuando, en realidad, somos seres simbólicos, capaces de crear irrealidades, de crear cultura. Animales, sí, pero con vida humana. La radical especificidad humana no está en la biología. Además de naturaleza, somos historia: recordamos el pasado, reflexionamos sobre el presente y proyectamos el futuro. Hay que seguir con la ciencia, pero hay que recuperar de nuevo el encantamiento del mundo, el sentido de lo sagrado, la presencia de Dios en la tierra por la acción creadora del hombre que busca la justicia, que se hace prójimo del hombre malherido en el camino (Lc 10, 36-37).

El humanismo de Cervantes está lejos de las consideraciones terroríficas de los ascetas de la Contrarreforma. "Mirar toda mi corrupción y fealdad corpórea; mirarme como una llaga y postema de donde han salido tantos pecados y tantas maldades y ponzoña tan turpísima"170. Los discípulos de san Ignacio siguieron fieles por este camino. Para el P. Alonso Rodríguez el cuerpo es "materia hedionda y sucia, vaso de estiércol, manjar de gusanos, muladar cubierto de nieve". "Lodo y polvo" es para el P. Luis de la Puente. El P. Nieremberg, con su sentido macabro de la vida y de la muerte, va más adelante: "es nombre muy soberbio llamarse polvo y lodo, y hasta gusano y podredumbre"171. De las descripciones de los cadáveres y de las sepulturas es mejor no hablar. ¡Con qué gusto hozaban en las entrañas de los muertos! ¡Hasta qué extremos de hediondez se llegaba en la predicación, en los libros de espiritualidad, también en el teatro y en la pintura! Todos reconocían que el cuerpo, en su origen, era obra de Dios, pero el pecado lo había convertido en materia fétida, enemigo del alma. "La substancia del cuerpo y del alma, ella de sí es buena y obra de Dios y, si llegamos la cosa a su principio, la tenemos solo de Dios"172. Fray Luis era lector de san Agustín: "Si tu carne es cárcel, no lo es tu cuerpo, sino la corrupción de tu cuerpo. Tu cuerpo es bueno, porque lo hizo Dios, que es bueno"173. Todo esto está muy bien, pero de hecho, en la situación actual, el cuerpo es corruptible, desorden y desconcierto, manjar de gusanos, como dirían los hombres del barroco.

170 San IGnAcio De LOYOLA, "Ejercicios espirituales", ib., edic. cit., nº 58, p. 172.

171 Cf. MARCos Villanueva, B., La ascética de los jesuitas en los autos sacramentales de Calderón, Universidad de Deusto 1973, pp. 170-173.

172 LEÓn, fray Luis de, De los nombres de Cristo, edic. cit., 1. 1, Padre del siglo futuro, p. 273.

173 San Agustín, Comentarios a los salmos 141, 18. 
En la "depravada naturaleza nuestra", Cervantes acierta a ver "la compostura del hombre, tan ordenada, tan perfecta y tan hermosa". En él triunfa el amor a la vida, la alegría de sus tiempos en Italia, añorados siempre desde la severa adustez castellana. Bello es el cuerpo de Grisóstomo, que, "aunque muerto, mostraba que vivo había sido de rostro hermoso y de disposición gallarda"174.

Escribiendo una comedia de santos, era inevitable tratar de la mortificación corporal, que purifica y esclarece el cuerpo aproximándolo a su primer esplendor. El cuerpo leproso del P. Cruz con la muerte quedó transfigurado, como un anticipo de la resurrección de la carne. "¿Que es este el rostro que yo vi ha dos días / de horror y llagas y materias [pus] lleno? / ¿Las manos gafas [leprosas] son aquestas, cielo? / ¡Oh alma, que, volando a las serenas / regiones, no dejaste testimonio / del felice camino que hoy has hecho! / Clara y limpia la caja do habitaste, / abrasada primero y ahumada / con el fuego encendido en que se ardía, / todo de caridad y amor divino [...]. / Hagan su oficio, padres, y en la tierra / escondan esta joya tan del cielo; / esa esperanza nuestro mal remedia"175. "Para señal de que aquel cuerpo había sido cristiano"176 pusieron una cruz encima de la sepultura de Cloelia, que se quedó esperando la resurrección allá en las tierras septentrionales. En el combate cristiano, hay que mortificar el cuerpo y purificar la memoria: "Y aquél que no ha gustado de la guerra, / a do se aflige el cuerpo y la memoria, / parece Dios del cielo le destierra"177. Los santos han llevado "vida de ángeles en cuerpos humanos"178. Pero Cervantes ni huye de la materia ni rechaza el cuerpo. Su visión de la vida no es ascética, aunque sí cristiana. Sobre las mortificaciones, ayunos y disciplinas habría mucho que hablar, pero no este el lugar adecuado.

Con frecuencia encontramos expresiones en las que nos parece oír el eco de numerosos textos espirituales. No olvidemos que la religión lo dominaba todo y en todo penetraba. Todos los ámbitos de la vida, privada y pública, estaban sujetos a ella. El lenguaje religioso no quedaba recluido en las iglesias y monasterios. Salía afuera, en los hogares y en las plazas, en la conversación de las gentes sencillas y en las cultas, en novelistas y dramaturgos, en poetas y eruditos, en la cháchara de las ventas y en el parloteo de

$174 Q M, \mathrm{I}, 13,157$.

$175 R D, \mathrm{III}, 364$.

$176 P S, \mathrm{I}, 6,173$.

$177 P, 4,44$.

${ }^{178} Q M$, I, 33, 419. 
los mercados. Y con las palabras, por muy rutinarias que fueran, se moldeaba el pensamiento y la vida.

Se pide socorro a la Virgen "antes que este mortal corpóreo velo / quede sin alma en esta tierra dura"179. "Oh alma venturosa, / que del humano velo / libre al alta región viva volaste, / dejando en tenebrosa / cárcel de desconsuelo / mi vida [...]. / Dejar libre y' desnuda / tu alma del mortal velo hermoso"180. "Almas dichosas, que del mortal velo / libres y exentas [...]."181. El alma "dejó la cárcel de su cuerpo estrecha"182. "Ese cuerpo, señores, que con piadosos ojos estáis mirando, fue depositario de un alma en quien el cielo puso infinita parte de sus riquezas" 183 . Un cantor sube al navío donde va Periandro, "aunque creo que con mucha brevedad le dejaré libre de la carga de mi cuerpo"184. "Cómo este miserable cuerpo quedará un día consumido del dolor poco a poco [...]. Yo te prometo y juro que el poco tiempo -que será bien poco- que esta apasionada ánima mía rigiese la pesada carga de este miserable cuerpo, y la voz cansada tuviese aliento que la forme [...]"185. Las almas son iguales, pero "según la caja y temperamento del cuerpo donde las encierra, así parecen ellas más o menos discretas"186. "Que yo encubro en esta funda / un alma de Dios sedienta"187. El cuerpo es "caduco, frágil y vano"188. "Recogí los suspiros, creyendo que con la fuerza que les hacía reventarían por parte que abriesen puerta al alma, que tanto deseaba desamparar este miserable cuerpo" 189 .

Caja, funda, carga, depósito, velo, cárcel del alma es el cuerpo. Son voces extrañas al cristianismo, pero que entraron muy pronto en él a través de los pitagóricos y de los platónicos.

\subsection{El alma: creación, destino y naturaleza}

Dios crea las almas y les señala ún destino, que no es otro que Él mismo. Dios creó al hombre, "cuya alma es capaz de la gloria que los ángeles malos

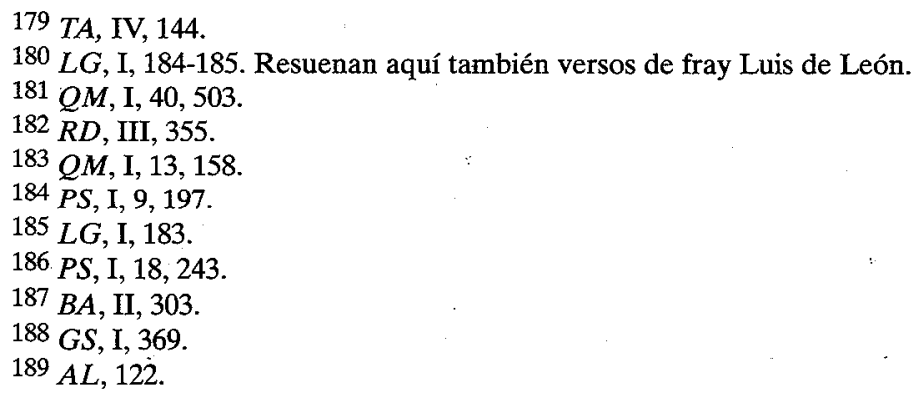


perdieron"190. Las almas "no pueden parar ni sosegar sino en su centro, que es Dios, para quien fueron criadas"191. "Un alma de Dios sedienta"192.

"Y tan capaz es el alma del sastre para ser poeta como la de un maese de campo; porque las almas todas son iguales y de una misma masa en sus principios criadas y formadas por su Hacedor, y, según la caja y temperamento del cuerpo donde las encierra, así parecen ellas más o menos discretas y atienden y se aficionan a saber las ciencias, artes o habilidades a que las estrellas más las inclinan"193. "Si las almas son iguales, / podrá la de un labrador / igualarse por valor / a las que son imperiales"194. "Tanta alma tengo yo como otro, y tanto cuerpo como el que más"195, dice Sancho.

La doctrina sobre la igualdad de las almas tuvo sus más y sus menos. En 1277, el arzobispo de París condenó esta teoría. Si fuera cierta, el alma de Cristo no hubiera sido superior a la de Judas Iscariote. Los seguidores de santo Tomás no se ponían de acuerdo sobre lo que había defendido. En España era común: Huarte de san Juan, Cervantes, Lope de Vega, Quevedo, Calderón ${ }^{196}$... Fray Luis de León, en cambio, defendió que las almas pertenecían todas a una misma especie, pero dentro de ella unas eran más perfectas que otras "en sí y en su substancia", como destinada que estaba cada una a un cuerpo distinto, porque "Dios labra las ánimas y los cuerpos de manera que sean conformes"197. Si las almas son todas iguales, ¿a qué se debían las diferencias? A causas orgánicas, a los humores corporales (sangre, atrabilis o humor negro, bilis, flema o pituita), a los temperamentos (sanguíneo, atrabiliario o melancólico, colérico, flemático o pituitoso), que se correspondían con los cuatro elementos (fuego, tierra, aire, agua) y con cualidades esenciales (caliente, frío, seco, húmedo), y todo ello nacía de determinados órganos secretorios (corazón, bazo, hígado, cerebro) ${ }^{198}$. A esto había que añadir el habitat geográfico y social y la influencia de los astros.

190 PS, IV, 5, 657

191 PS, III, 1, 429.

$192 B A$, II, 303 .

193 PS, I, 18, 242-243. Maese (maestre) de campo era el jefe de un tercio.

194 GI, 94 .

$195 Q M$, I, 50, 627.

196 GREEN, Otis H., ib., II, c. 4, pp. 168-172.

197 LeÓn, fray Luis de, De los nombres de Cristo, edic. cit., 1. 3, Cordero, p. 578. Cf. GuTIÉRrez, M., "Fray Luis de León y la filosofía española del siglo XVI", en Obras completas", Real Monasterio de El Escorial 1929, t. I, c. 5, pp. 155-158.

198 Cf. AvAlle-ARCE, J. B., Don Quijote como forma de vida, Castalia, Madrid 1976, c.4, pp. 116-117. 
El alma no envejece y es inmortal. "Mortales y caducas hermosuras / no satisfacen a la inmortal alma, / si de la luz perfecta no anda a oscuras"199. "Mas como los vicios tienen asiento en el alma, que no envejece, no quieren dejarme"200. Alguien, al caer de espaldas, "dio el cuerpo al suelo y el alma adonde Dios se sabe"201. En muchos textos en los que Cervantes habla de la muerte, del cielo o del infierno se hace presente la inmortalidad del alma. El cielo es la patria del alma: "Y puesto que subo tanto / en amar cosa mortal, / tal bien encierra mi mal, / que el alma por él levanto / a su patria natural" 202 .

"-¿Alma tenéis los cristianos? / -Sí; y tan ricas y extremadas / cuanto por Dios rescatadas"203. El P. Cruz se anima a sí mismo a luchar contra el demonio: "¡Oh alma!, mira quién eres, / para que del bien no tuerzas"204. Dorotea espera que don Fernando cayese "en la cuenta de que era cristiano, y que estaba más obligado a su alma que a los respetos humanos"205. Don Fernando daba gracias al cielo por "haberle sacado de aquel intrincado laberinto [de las pasiones], donde se hallaba tan a pique de perder el crédito y el alma"206.

"Más obligado a su alma que a los respetos humanos". Castro ha visto en esta frase "el plan y designio del Quijote"207, libro que considera "una forma secularizada de espiritualidad religiosa" 208 , una forma secularizada de la religión de los cristianos nuevos o conversos. Los personajes se hacen a sí mismos desde su moradas íntimas, desde sus almas, sin atender a los respetos humanos ni apoyarse en trascendencias, dice Castro. Es el tema del individuo frente a la sociedad, del "sé quién soy" contra el "mira quién eres" del estado social. Lo que Dorotea, que, como dice Castro, "tan calculada y discretamente supo manejar su sexo y sus esperanzas de ser gran señora", dice a don Fernando es que se deje de respetos humanos -era hijo de duque, rico y prepotente- y cumpla, como buen cristiano, la palabra que le dio de matrimonio. Nada más y nada menos. Se apela a la trascendencia, a su condición de cristiano. El hacerse los personajes desde sí mismos y el

$199 L G$, III, 312.

200 PS, I, 20, 260.

$201 P S$, III, 6, 490

202 LG, VI; 98.

$203 T A$, I, 114.

$204 R D$, III, 359.

$205 Q M, \mathrm{I}, 28,362$.

$206 Q M, 1,37,475$.

207 CASTRo, A., Cervantes y los casticismos españoles, Alianza-Alfaguara, Madrid 1974, c. 1, p. 138 .

208 ÍD., ib., c. 1, p. 122. 
desarrollarse la estructura del libro desde dentro, sin atenerse a modelos y estilos de su tiempo, es una intuición certera de Castro; pero que esto se deba a la religiosidad interior de los conversos es lo que hay que demostrar. Demostrar, en primer lugar, esa supuesta religiosidad interior de los cristianos nuevos y, en segundo lugar, que el Quijote surja de ese limo. Los escritos que conocemos de los conversos varían mucho y hay grandes contrastes entre ellos. ¿En qué se parecen Góngora y Mateo Alemán, los dos descendientes de conversos? Castro mismo opone a Cervantes, que, según él, era converso, a santa Teresa, nieta de un judío convertido ¿En qué quedamos?209. Tanto Cervantes como sus personajes se mueven dentro del marco del catolicismo en dogma y moral, aunque discrepe en algunos puntos de moral sexual y devociones e ironice en bastantes ocasiones sobre el clero.

El alma se regocija y siente su plenitud en la fe y en la virtud. Se alaba el trato, la vida honrosa de Mateo Vázquez "y el alma dentro de virtudes llena"210. "Llegué a Roma, donde se alegró mi alma y se fortaleció mi fe"211. "Que las prendas que se compran a deseos y tienen su estimación en el alma del comprador, aquello valen que vale un alma, que no hay precio en la tierra con que aprecialla"212. En Lisboa, los peregrinos gastaron sus días "en visitar los templos y en encaminar sus almas por la derecha senda de su salvación"213. Los pensamientos de Auristela "por entonces no se extendían a más que de enterarse en las verdades que a la salvación de su alma convenían"214. Al despertarse de un profundo sueño, próximo ya a la muerte, don Quijote condena los libros de caballerías, que le hundieron "en las sombras caliginosas de la ignorancia", y se lamenta de no poder leer "otros que sean luz del alma"215. Visitando don Quijote una imprenta en Barcelona, vio que estaban imprimiendo un libro que se titulaba Luz del alma, y dijo: "Estos libros, aunque hay muchos deste género, son los que se deben imprimir, porque son muchos los pecadores que se usan y son menester infinitas luces para tantos desalumbrados" 216 . Se ha pensado que se trata del catecismo

209 Cf. Morón, C., ib., edic. cit., pp. 314-318.

$210 P, 34,58$.

$211 E I, 259$.

212 EI, 237.

213 PS, III, 1, 439.

214 PS, IV, 5, 651.

$215 Q M$, II, 74, 1330. Léase la nota a este pasaje. Cf. en el volumen complementario de esta edición, la lectura correspondiente al c. 74 de la segunda parte firmada por Bruce W. Wardropper, pp. 244-246. .

$216 Q M$, II, 62, 1251. 
Luz del alma cristiana, del dominico fray Felipe de Meneses, libro que denuncia la ignorancia religiosa de los españoles del siglo XVI217, "las sombras caliginosas de la ignorancia de tantos desalumbrados", como dice don Quijote. El libro fue impreso en Valladolid en 1554. Tuvo varias ediciones en el siglo XVI, aunque ninguna en Barcelona. Por eso se cree que se trata de un título genérico, sin aludir a ninguno en concreto. Don Quijote pide un confesor "que me confiese y un escribano que haga mi testamento, que en tales trances como éste no se ha de burlar el hombre con el alma [...]. Después de haber hecho la cabeza del testamento y ordenado su alma don Quijote [...]."218.

El pecado, en cambio, encadena al alma. No hay que dejar que eche raíces en ella. "De la incomparable honestidad de Isabela no se podía esperar otra cosa, ni aun él [Ricaredo] quisiera esperarla, aunque pudiera, porque la noble condición suya y la estimación en que a Isabela tenía no consentían que ningún mal pensamiento echase raíces en su alma"219. El pecado es siempre daño del alma, herida, peligro. "¡Que aqueste mozo me engañe / y que tan a suelta rienda / a mi honor y su alma dañe!"220, dice el inquisidor Tello. El rufián Lugo invoca el auxilio sobrenatural para "que yo ponga mis plantas / donde al alma no lastimen"221. "Yo, traidor, que a la gula, en sacrificio / del alma, y a la hampa engendradora / de todo torpe y asqueroso vicio [...]"222. Una viuda pone su gloria en diez mil ducados encerrados en dos cofres: "Y así, en verlos se desalma: / que han de ser para su alma / lo que a Absalón sus cabellos"223. Luisa la Talaverana confiesa: "No soy tan tonta que no conozca el peligro en que traigo el alma en este vagamundo estado"224.

El pecado de las brujas, que es pecado de carne y de deleites, las hunde en lo más profundo de su depravada naturaleza. La Cañizares no admite disculpa para su pecado: "La costumbre del vicio se vuelve en naturaleza, y éste de ser brujas se convierte en sangre y carne, y en medio de su ardor,

217 Sobre la ignorancia religiosa de los españoles del siglo XVI, tanto en los seglares como en el clero, cf. MENESES, F. de, Luz del alma cristiana, estudio preliminar y edición de Ismael Velo Pensado, Universidad Pontificia de Salamanca / Fundación Universitaria Española, Madrid 1978, pp. 240-258. 354-369; REsINES, L., Catecismos de Astete y Ripalda, edición crítica preparada por, BAC, Madrid 1987, pp. 12-15. M. Bataillon y A. Castro insistieron en el erasmismo del libro de Meneses, pero está claro que en él no hay rastro de erasmismo (cf. Morón. C., Para entender el Quijote, edic. cit., c. 10, pp. 305-309).

$218 Q M$, II, 74, 1331-1332.

219 EI, 219.

$220 R D, I, 333$.

$221 R D, \mathrm{I}, 342$.

$222 R D$, III, 356

223 PU, I, 513.

224 PS, III, 16, 585. 
que es mucho, trae un frío que pone en el alma tal, que la resfría y entorpece aun en la fe, de donde nace un olvido de sí misma, y ni se acuerda de los temores con que Dios la amenaza ni de la gloria con que la convida; y, en efecto, como es pecado de carne y de deleites, es fuerza que amortigüe todos los sentidos, y los embelese y absorte, sin dejarlos usar sus oficios como deben; y así, quedando el alma inútil, floja y desmazalada, no puede levantar la consideración siquiera a tener algún buen pensamiento; y así, dejándose estar sumida en la profunda sima de su miseria, no quiere alzar la mano a la de Dios, que se la está dando por sola su misericordia para que se levante. Yo tengo una de estas almas que te he pintado. Todo lo veo y todo lo entiendo, y como el deleite me tiene echados grillos a la voluntad, siempre he sido y seré mala"225. La Cañizares invita a Berganza para que vea cómo se unta, y él hace una descripción física de la bruja con rasgos de animalidad, horrorosa, degradante, grotesca, repulsiva -algo extraño en Cervantes-; de aquella vieja "flaca y endemoniada [...]. Comenzó a apoderarse de mí el miedo, considerando la mala visión de su cuerpo y la peor ocupación de su alma"226.

Sobre las brujas escribieron mucho los señores teólogos y desde los púlpitos tronaban contra ellas los predicadores. La persecución la desató la bula Summis desiderantes affectibus (1484), del papa Inocencio VIII, ante las noticias terribles que llegaban del centro de Alemania. Personas de uno y otro sexo se entregaban a los demonios íncubos y súcubos. Los demonios se transformaban en forma humana y tentaban a todos. Los súcubos (en forma de mujer) no producían descendencia, pero los íncubos (en forma de hombre) dejaban su semilla en las mujeres, que daban a luz hijos de Satán. ¡El mundo se llenaría de satanasicos! Las brujas con sus prácticas demoníacas destruían las cosechas, se reunían en aquelarres y danzaban en torno a un cabrón negro, el diablo, su dueño, donde daban rienda suelta a todas sus fantasías. Mataban a los niños en los vientres de sus madres y a los animales de toda especie, impedían que las mujeres pudieran concebir, e incluso que maridos y mujeres cumplieran con su deber conyugal, y así "otros muchos excesos y crímenes abominables", dice la bula. El tratado más famoso fue el Malleus maleficarum, de dos frailes dominicos alemanes, Enrique Institoris, conocido por Krämer, y Jacobo Sprenger, los dos inquisidores 227 . Se convirtió en el manual de inquisidores y jueces, que se entre-

$225 C P, 599$. Léase la nota 197.

226 CP, 601.

227 InSTITORIS, E.- SPRENGER, J., El martillo de las brujas, traducción de Miguel Jiménez Monteserín, Maxtor, Valladolid 2004. 
garon a la caza de brujas. Las brujas no existían, pero hasta las personas más sensatas creían en ellas y en sus maleficios. La creencia se hizo realidad y fue ella la que desató su exterminio.

También en España se quemaba a las brujas, aunque aquí no se llegó a la obsesión social de otras partes de Europa. Si se lee el episodio sobre ellas en El coloquio de los perros, se llega a la conclusión de que la brujería no es obra del demonio, sino de las alucinaciones que padecían por el ungüento de hierbas alucinógenas con que se untaban. ¡Qué páginas tan luminosas éstas de Cervantes sobre las brujas! Antes, el doctor Andrés Laguna había demostrado científicamente que esos desvaríos venían provocados por drogas. En 1610, tres años antes de que Cervantes publicara su novela, el inquisidor Alonso de Salazar y Frías, el" abogado de las brujas"228, intervino en el proceso incoado por la Inquisición a las brujas de Zugarramurdi y de Urdax. Recorrió toda la Navarra rural, interrogó a 1802 personas acusadas de brujería (1384 eran niños), estudió los procesos anteriores de la Inquisición contra las brujas y elaboró un informe para la Suprema: "Y así, regulando todo en la igualdad y rectitud conveniente, he tenido y tengo por muy más que cierto que no ha pasado real y corporalmente ninguno de todos los actos deducidos o testificados en este negocio" 229 . Su conclusión fue demoledora: "No hubo brujos ni embrujados en el lugar hasta que se comenzó a tratar y escribir de ellos". El Inquisidor General, don Bernardo Sandoval y Rojas, protector de Cervantes, aceptó su informe, y se publicó el "edicto del silencio".

Un cautivo se queja de estar "en poder de esta gente que no alcanza / razón, virtud, valor, almas, conciencia" 230 . Y el mayor insulto que se le puede decir a don Quijote, y por eso reacciona ofendido, es decirle que el que dio libertad a los galeotes "debe de ser tan gran bellaco como ellos, o algún hombre sin alma y sin conciencia"231. "Gente con cuerpos desalmada"232, se dice de los ingleses en la segunda canción a la Armada Invencible.

El alma es la forma que vivifica el cuerpo. Dice Auristela: "Así puedo yo vivir sin Periandro como puede vivir un cuerpo sin alma. Allí tengo de

228 Henningsen, G., El abogado de las brujas. Brujería vasca e Inquisición, Alianza, Madrid 1983.

229 Cit. por Caro Baroja, J., Las brujas y su mundo, Alianza, Madrid 1966, p. 237. Cf. Fernández Álvarez, M., Casadas, monjas, rameras y brujas, Espasa Calpe, Madrid 2002, c. 7, pp. 287-323; Bombín PÉrez, A., La Inquisición en el País Vasco. El tribunal de Logroño (1570-1610), Universidad del País Vasco, Bilbao 1997, c. 6, pp. 189-201.

230 TA, III, 132.

$231 Q M, \mathrm{I}, 29,377$.

$232 P, 38,62$. 
vivir donde él viviere: él es el espíritu que me mueve y el alma que me anima"233. "Es mi alma, por lo menos: por él vivo, por él respiro, por él me muevo y por él me sustento"234. "He dicho mal en partir estas dos almas, pues no son más que una" 235 en el Uno (neoplatonismo y agustinismo). Se recuerda la teoría de Platón según la cual el saber de las almas es acordarse de lo que ya sabían; pero se inclina por la teoría aristotélica que afirma que el alma es una tabla rasa en la que no hay nada pintado ${ }^{236}$. Se dice que nuestras almas están siempre en continuo movimiento. "El deseo presupone falta de lo deseado, y hasta conseguirlo es forzosa la inquietud del ánimo nuestro"237. "Bien sé que nuestras almas están siempre en continuo movimiento, sin que puedan dejar de estar atentas a querer bien a algún sujeto a quien las estrellas las inclinan, que no se ha de decir que las fuerzan"238. Habrá que tener presentes estos textos al hablar de Dios como centro del hombre. El alma tiene "tres potencias [memoria, entendimiento y voluntad] y cinco sentidos"239. "La obligación en que quedé de servirte el punto que en mis potencias se imprimió el conocimiento de tus virtudes" 240 .

\subsection{El espíritu}

Los términos alma y espíritu son sinónimos en algunos textos de Cervantes. Erasmo recuerda que Orígenes, siguiendo a san Pablo, distinguió tres partes en el hombre: espíritu, alma y carne. La carne y el alma nos vienen de Adán. El espíritu, que nos da la verdadera vida del alma, nos lo da Cristo $^{241}$. El espíritu nos hace divinos; el alma, hombres; la carne, bestias. Nada de esto aparece en Cervantes, como tampoco habla del hombre interior y del hombre exterior, que aparece con frecuencia en Erasmo, y antes en san Agustín y en san Pablo. En otros textos espíritu significa 'intención', 'vivacidad de ingenio', 'inspiración'.

233 PS, II, 7 (segunda parte), 324.

234 PS, IV, 11, 694.

235 PS, IV, 1, 629.

${ }^{236}$ Cf. $L G$, IV, 452; QM, II, 46, 1094; PS, IV, 10, 690; MALÓN DE ChaIDE, P., La conversión de la Magdalena, Espasa-Calpe, Madrid 195733, t. II, c. 31, pp. 146-148.

237 LG, IV, 444.

238 PS, II, 3, 293.Sobre el movimiento del alma, cf. GuTIÉRrez, M., "Fray Luis de León y la filosofía española del siglo XVI", en Obras completas, edic. cit., t. I, adiciones al c. 4, pp. 474-475, y adiciones al c.5, pp. 502-503.

$239 T F, 641$.

240 PS, II, 7 (primera parte), 320.

241 ERASMo, El Enquiridion o Manual del caballero cristiano, edición de Dámaso Alonso, CSIC, Madrid 1971, cs. 6-7, pp. 175-192 
"Me precio de la estrecha amistad y conversación que siempre tuve con la bendita alma del cuerpo que en esta sepultura yace, dice la musa Calíope, cuyas obsequias, por vosotros celebradas, no sólo han alegrado su espíritu, que ya por la región eterna se pasea"242. "Con fatigado aliento y laso [cansado] espíritu"243. "Horas hay de recreación, donde el afligido espíritu descanse 244 . Periandro "es el espíritu que me mueve y el alma que me anima"245. Don Diego Miranda invita a don Quijote a descansar en su casa "del pasado trabajo, que si no ha sido del cuerpo, ha sido del espíritu, que suele tal vez redundar en cansancio del cuerpo"246. Don Quijote comparte los dolores de Sancho: "Más dolor sentía yo entonces en mi espíritu que tú en tu cuerpo"247. El espíritu se contrapone a la carne como se contrapone el alma al cuerpo. Perdonar a los enemigos es difícil "para aquellos que tienen menos de Dios que del mundo y más de carne que de espíritu"248. Y este texto bíblico: "Que puesto que [aunque] estaban prontos con el espíritu a recibir martirio, todavía la carne enferma rehusaba su amarga carrera"249. Morir es entregar el espíritu, separarse el alma del cuerpo. "¡Que no me hallara yo a tu cabecera, / cuando diste el espíritu a los aires, / para que le acogiera entre mis labios, / y en mi estómago limpio le envasara!"250. Era el beso en la boca al moribundo para recoger su postrer aliento, su espíritu. Don Quijote, "entre compasiones y lágrimas de los que allí se hallaron, dio su espíritu; quiero decir que se murió"251. "Doquier que estés, te buscaré, viviendo, / o ya desnudo espíritu sin carne"252. "De Merlín el espíritu encantado / soy"253.

Los manteadores, "casi como instigados y movidos de un mesmo espíritu [intención], se llegaron a Sancho"254. "Siendo, pues, ansí que las armas requieren espíritu [vivacidad de ingenio] como las letras, veamos ahora cuál de los dos espíritus, el del letrado o el del guerrero, trabaja más"255. No falta

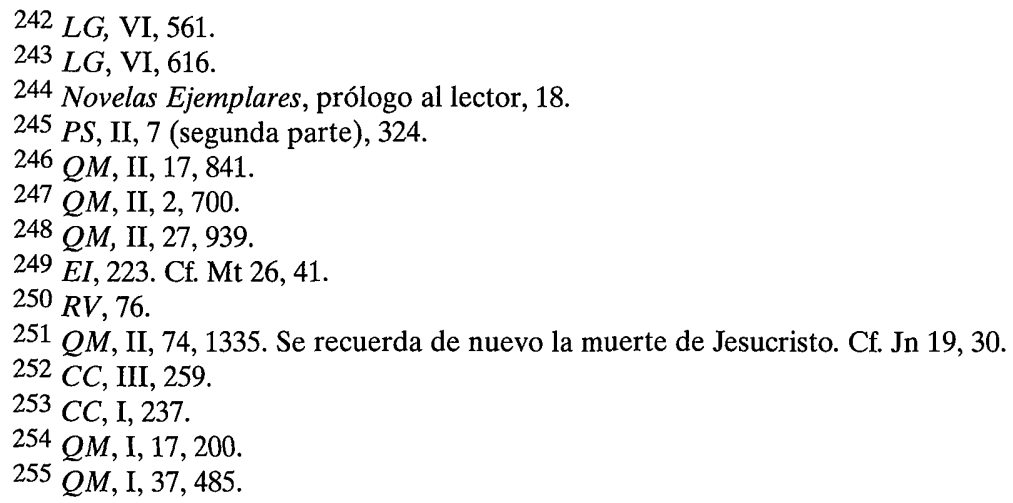


el diminutivo gracioso y vivaz, el duende creativo andaluz. "Tengo un cierto espiritillo fantástico acá dentro, que a grandes cosas me lleva"256.

Hay textos en los que espíritu significa inspiración. "Pasó el sobresalto, volvieron los espíritus de los retraídos a su lugar, y el jadraque, cobrando aliento nuevo, volviendo a pensar en la profecía de su abuelo, casi como lleno de celestial espíritu, dijo"257. "Revistiéndosele a Transila el mismo espíritu que tuvo el tiempo que se vio en el mismo acto y ocasión que su padre contaba, levántándose en pie, con lengua a quien suele turbar la cólera, con el rostro hecho brasa y los ojos fuego [...]"258. "Un cierto espíritu, dice Periandro, se entró entonces en mi pecho, que, sin mudarme el ser, me pareció que le tenía más que de hombre y, así, levántándome en pie sobre la barca, hice que la rodeasen todas las demás" 259 e invita a sus compañeros a hacerse piratas justicieros. Don Quijote se dispone a pronunciar el discurso sobre las armas y las letras: "Dejando de comer, movido de otro semejante espíritu que el que le movió a hablar tanto como habló cuando cenó con los cabreros" 260 .

José Vega Blanco

Estudio Teológico Agustiniano

Valladolid

$256 G I, 54$. Léase la nota a este pasaje. "Y como la necesidad, según se dice, es maestra de avivar los ingenios, este mío, que tiene un no sé qué de fantástico e inventivo" ( $P S, I V$, 1, 631).

257 PS, III, 11, 553.

258 PS, I, 12, 216.

$259 P S$, II, $12,360$.

${ }^{260} Q M, I, 37,484$. 